\title{
The Glendoe Tunnel Collapse in Scotland
}

\author{
S. R. Hencher ${ }^{1}$
}

Received: 2 June 2018 / Accepted: 6 April 2019 / Published online: 17 April 2019

(c) The Author(s) 2019

\begin{abstract}
For Glendoe hydro-electric scheme in Scotland, the tunnelling contract was design-build. After a year, the tunnel collapsed, blocking a 71-m length, which necessitated construction of a by-pass tunnel. The responsibility for the collapse was examined in court and the findings were later appealed by a further three judges. The judge of the first case found that the cause of the failure was "erodible rock" and the other three judges agreed, but, it is argued, that there is evidence for a complex wedge failure at a scale larger than the geological mapping. It is considered that the Owner of the tunnel, Scottish Southern Electricity took on the risk by agreeing to a TBM-constructed, mostly unlined tunnel rather than a drill and blasted, fully lined tunnel as had been postulated at tender. The Contractor, Hochtief, constructed the tunnel and lined it in accordance with a Rock Excavation Classification design sheet that was agreed by all parties and approved by the Engineer. A clause, 'Option M' limited the responsibility of the Contractor "for defects in the works due to his design so far as he proves that he used reasonable skill and care to ensure that it complied with the works information". The question is posed as to whether or not the current judicial process may be an impediment to valid decision-making on responsibility for dealing with complex geotechnical problems. This paper suggests that these issues require a technical assessment and engineering judgement decision, rather than a legal opinion, adjudicated on the basis of opined contractual responsibility. Perhaps, an erudite technical panel deliberation rather than a judicial process should be given the final authority in such cases.
\end{abstract}

Keywords Geotechnical risk · Tunnels $\cdot$ Failure $\cdot$ Joints $\cdot$ Faults $\cdot$ Arbitration $\cdot$ Court

\section{Introduction}

There is always risk in carrying out engineering works below ground because of geological variability, the difficulties in producing a representative model and problems with deciding on parameters. Geotechnical risk is dealt with contractually in 'design-bid-build' contracts by various methods, as illustrated in Fig. 1. The Engineer, working directly for the Owner/Client, designs the works and instructs the Contractor whose tender is successful, on how to proceed. For simple sites, all risks might be taken by the Owner. Alternatively, where little is known about the conditions to be encountered, all ground risk might be accepted by the Contractor. Contractual alternatives include sharing the risk somehow. This is often done by incorporating 'Clause 12' conditions of the ICE Conditions of Contract, 7th Edition,

S. R. Hencher

stevehencher@btinternet.com

1 Hencher Associates Limited, University of Leeds, The University of Hong Kong, Leeds, UK which allows for physical conditions that could not have been foreseen by an experienced contractor to be paid for.

Where the Engineer and Contractor disagree over the interpretation of the Engineer, this may lead to litigation, wherein the nature and amount of ground investigation, that was instructed by the Engineer, may turn out to be a factor.

A second type of contract, as used at Glendoe, is 'design-build'. The Owner/Client may be advised separately by a consulting engineer (in the Glendoe case, by Jacobs), who conducts a partial site investigation and prepares a preliminary design for the envisaged works. That preliminary design of the works is then let for tender, examined by various contractors during the tendering phase, one of whom will be later contracted to carry out further site investigation (possibly) and the final design of the works. He will then construct the works, to be supervised and approved by a consulting engineer advising the Owner/Client.

The risk of unexpected ground conditions still exists under design-build contracts, but the common law position is that the risk of unforeseen ground conditions rests with the Contractor. An area where geotechnical risk can become 
Fig. 1 Options for addressing the risk of unexpected ground conditions in a design-bidbuild contract (after Hencher 2012)

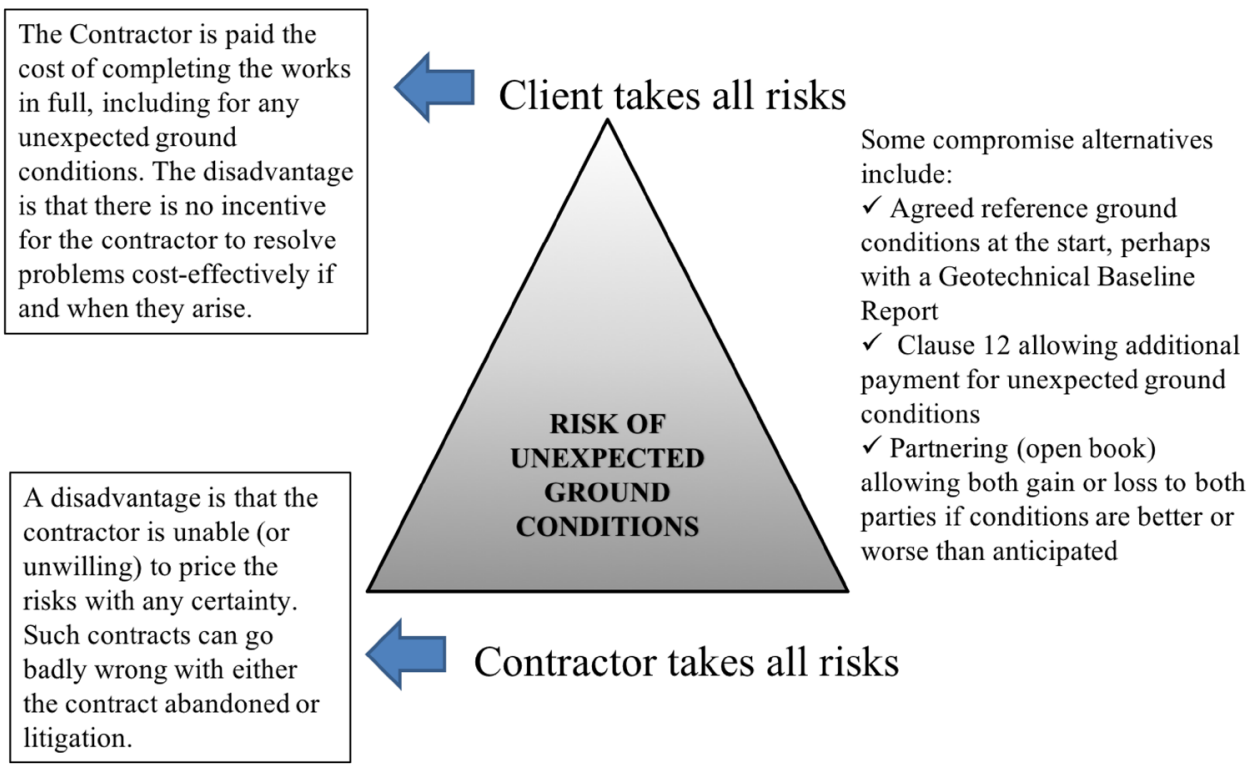

dominant in that form of contract is regarding the quality of the final works and the approvals thereof.

For the Glendoe hydro-electricity project, which will be discussed in detail later, the headrace tunnel was originally designed by the Owner's engineer, Jacobs, to be constructed by drill and blast and to be fully lined (Carloway 2018, para 22). The Owner, Scottish Southern Electricity Generation limited ('SSE') was persuaded during tender by Pöyry Energy JV ('Pöyry'), Hochtief Solutions AG ('Hochtief'), the tendering contractor's design engineer, to accept a TBM-constructed tunnel which should result in a much smoother finish with less over-break. Pöyry predicted that the lining requirement could be reduced to $40 \%$ for a TBM-constructed tunnel, compared to the $100 \%$ anticipated for a tunnel constructed by drill and blast (Carloway 2018, para 23). In the event, the project was accepted and then constructed by Hochtief taking decisions on lining requirements "at the face, based on actual conditions" (Woolman 2016, para 38) with, in the event, less than $1 \%$ of the headrace tunnel being fully lined (Woolman 2016, para 67). The tunnel was finished and inspected "on a metre-by-metre basis in 2008" by Hochtief, Pöyry, Jacobs and SSE which "only uncovered several minor issues which were resolved before watering up" (Woolman 2016, para 181). The construction of the tunnel was approved [by Jacob's approval of the 'rock excavation sheets' ('REC') on behalf of SSE, according to Woolman 2016, para 185] albeit that there remained a 'defects period' for 2 years after take-over. The contractor avoided the consequence of 'a defect that existed at takeover' through 'Option M' of the contract, which excluded "liability for defects due to the contractor's design if he proved that he used reasonable skill and care that his design complied with the "works information"" (Carloway 2018, para 5). It seems evident that the close inspections by all parties following construction established the case of reasonable care, and the formal approval of the RECs by Jacobs showed that the contractor took account of the 'works information' adequately.

The system was 'watered up' and then, over an 8-month period, a 71-m length of tunnel collapsed and became blocked. This led to a dispute which was initially referred to an adjudicator, Robert Galbraith QC, appointed by both parties, for a decision. He held that "there was no defect which existed at take-over since the rock support specified and installed was appropriate for the purposes of the contractual terms". He concluded that "the damage which occurred after the works had been taken over was an employer's risk" (Carloway 2018, para 51).

If the decision of adjudication is not accepted by the parties, as was clearly the case at Glendoe, then the final step might be resolution via an arbitration (the results from which would remain private to the parties). As an alternative to arbitration, the matter may be litigated in court, as for the Glendoe headrace tunnel. The disadvantage of a court process is that the facts may be assessed by nontechnically qualified judges on the basis of legal issues rather than by a technically qualified, independent, professional engineer based on geotechnical matters (Winter 2000). Furthermore, the results are not held 'private and confidential', there is every chance of an appeal, and all the 'opinions' are made available for public consumption as court records. Before examining the Glendoe evidence and the decision-making, there is a need to address the concept of geotechnical risk, because it is not simple. 


\section{Geotechnical Risk}

Geotechnical risk can be very difficult to identify, depending on the geological conditions and the nature of the works. Complex geology does not automatically lead to geotechnical risk (Morgenstern and Cruden 1977) and, conversely, apparently simple ground conditions can cause problems if crucial factors are overlooked (Hencher 2012, Chapter 7). Note that in the following text, the term 'risk' is equated to 'hazard', whereas strictly, risk is assessed as probability of hazard occurrence multiplied by the consequence.

Baecher and Christian (2003) split the sources of geotechnical 'risk' into three categories:

1. Natural variability (aleatory)

2. Knowledge uncertainty (epistemic)

3. Decision model uncertainty

The first two are interlinked-natural variability relates to the ground itself which might, for example, be a simple series of beds, strengthening with depth. Conversely, the ground might comprise a severely weathered and variable profile or an intensely structurally folded and faulted geology, as is the case for the Glendoe headrace tunnel. Knowledge uncertainty can be reduced by increasing the amount of geotechnical investigation. Doubling or tripling the number of boreholes should help to reduce this risk but would not remove it completely. Baecher and Christian suggest that the first two sources of risk, natural and knowledge uncertainty, need to be dealt with by statistical methods although there are different viewpoints. Expert geological modelling, which aids the knowledge of variability within a causative model can be useful (Fookes 1997). The Decision Model by definition must be based on quantified assessment of the first two, judging the variability and information available, and deciding on how to proceed.

Where one has $100 \%$ rock exposure in the walls of a tunnel, with a very high potential percentage of knowledge of the natural variability in essentially two dimensions, as at Glendoe, and experts who have examined the exposed rock judge the risk to be low, then is the risk low? And later, when the tunnel collapses, where does the responsibility for the evident risk that was inherently present (though invisible to the expert's eyes) but which developed at a later stage, fall? Is it the expert's fault (whose understanding of the problem or appreciation of true conditions might have been lacking) or the risk of the Owner, who agreed the criteria for acceptance of the tunnel? I will illustrate this dilemma with two examples followed by detailed discussion of the case of the tunnel collapse at Glendoe.

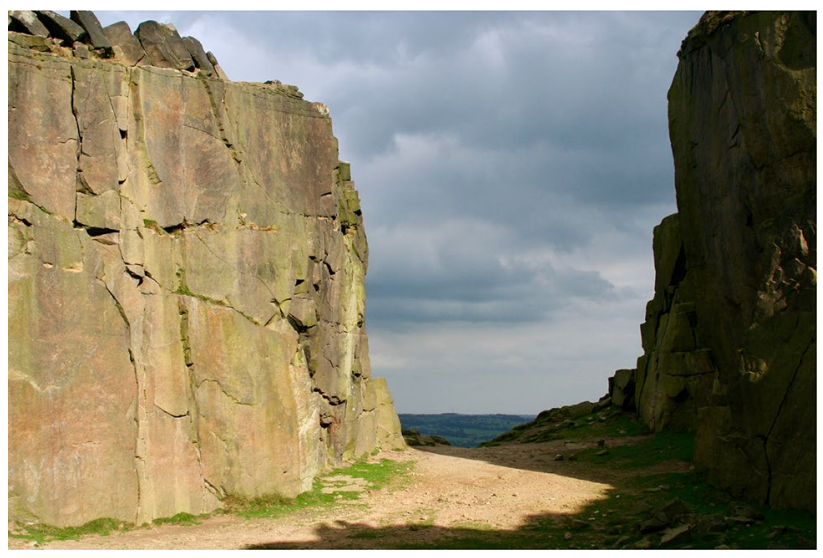

Fig. 2 The Cow and Calf Quarry, Ilkley, West Yorkshire, UK

\subsection{Example Case 1-Ilkley Moor Quarry}

MSc students in Engineering Geology at the University of Leeds are trained in logging rock discontinuities and examining the potential for slope failure on these discontinuities during an annual university field class. This field class was conducted for several years in the Cow and Calf Quarry, at Ilkley Moor, Yorkshire, UK (Fig. 2). Students would be split into groups to conduct line surveys of discontinuities along the base of the quarry, and at higher levels as access allowed. After a few years of conducting surveys at the quarry, it was decided, because of the lack of geotechnical interest or features to describe, to move the exercise to another, larger quarry on the moor, where there are more joints and faults to be examined. The walk to the new location took the students past and above the previous quarry. Imagine the surprise when, a couple of years later, it was noted that a large corner section of the previous quarry field-class location had collapsed (Fig. 3). The failure had occurred on a combination of steeply dipping joints that were probably not daylighting in the quarry and probably involved some local intact failure of the partially weathered rock. The students were called together and warned to remember this case as evidence that no one, not even a cohort of supervised MSc students conducting a survey to predict slope failure, is infallible in spotting a serious geotechnical hazard.

\subsection{Example Case 2-The Chinese University Slope, Hong Kong}

Halcrow consulting engineers were commissioned to assess the need for and to design preventative measures to prevent rock fall or larger-scale failure at a series of slopes that were cut along various public roads in Hong Kong at the Chinese University. A query was raised by the Client regarding the preventive measures that were being proposed, which largely comprised pattern rock dowelling and netting. It was 


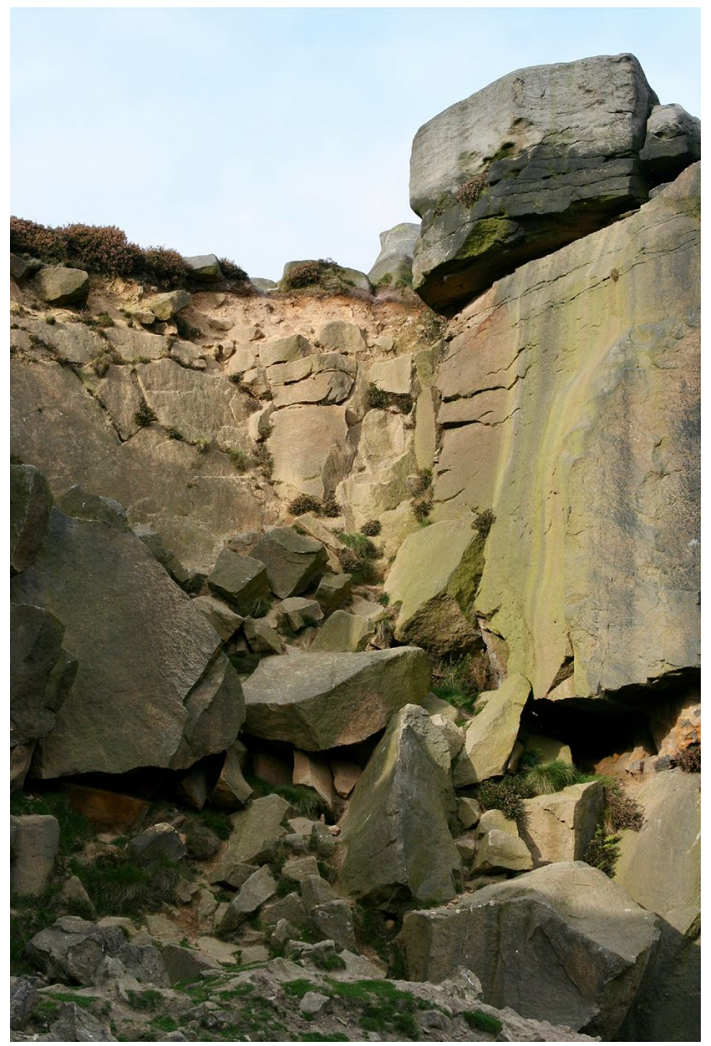

Fig. 3 Unexpected failure in the corner of the Cow and Calf Quarry

considered by one of the Client's advisors that the measures proposed by Halcrow were excessive. A visit was made to the site by a Halcrow director with other geotechnical engineers to examine the rock in detail. It was observed that there were slabs of steeply dipping rock, many of which were undercut and some showing some degree of opening. That condition, combined with the knowledge of a history of rock falls at the site, led to the conclusion that the proposed measures by the engineers were essentially correct and appropriate (Figs. 4, 5). The Client disagreed on the basis of advice from a separate consultant, and proceeded to terminate the Halcrow contract, opting for some reduced measures; it is unknown what works were actually carried out to the slopes. This simply illustrates that geotechnical opinions may differ about situations, and that the Client can adopt a riskier path, if he so chooses, and is so advised.

\section{The Glendoe Headrace Tunnel}

The Glendoe headrace tunnel is part of the works associated with the construction of a $100 \mathrm{MW}$ hydroelectric scheme, owned by Scottish and Southern Energy plc (SSE) in the Monadhliath Mountains in Scotland. The $£ 145$ million tunnel was constructed by Hochtief Construction AG Major

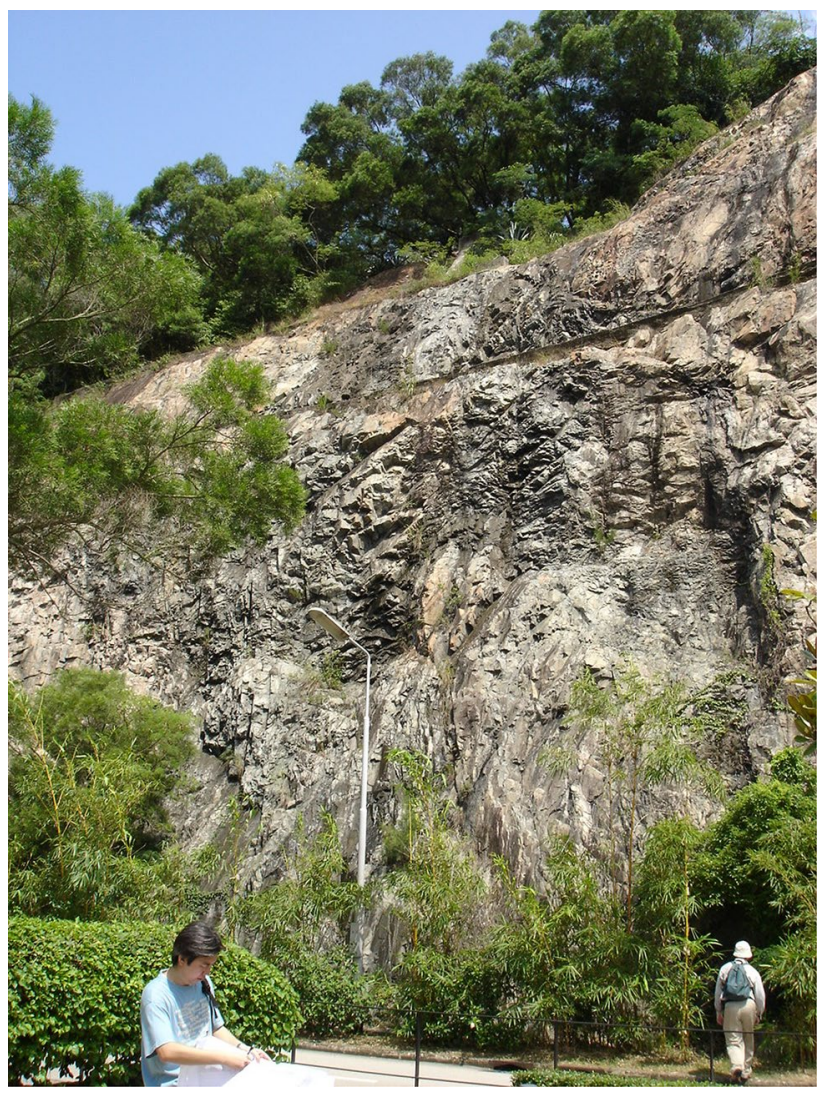

Fig. 4 The Chinese University rock cut slopes, Hong Kong

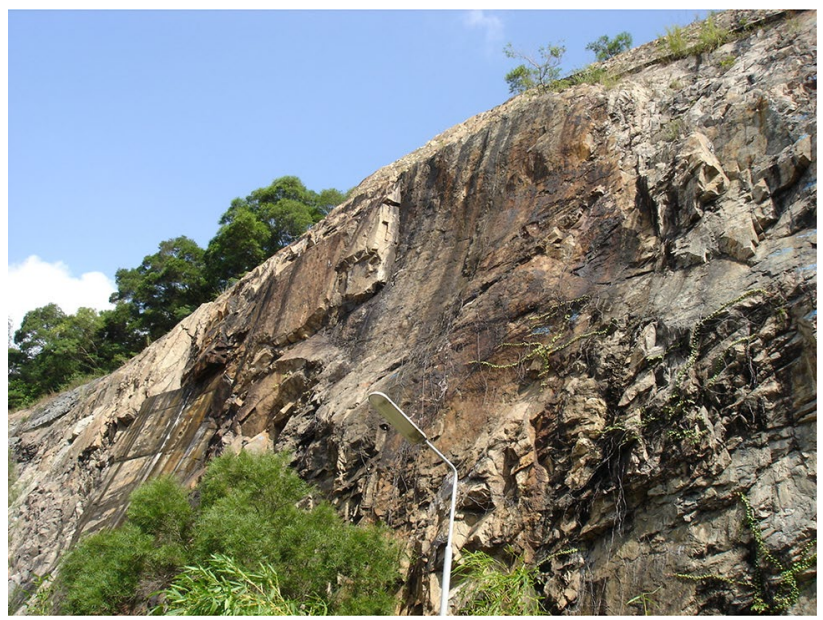

Fig. 5 Undercut blocks sitting on steeply dipping planes

European Projects (Hochtief), together with its UK tunnelling subsidiaries. It was the first such tunnel to be constructed in Scotland since 1957.

A collapse occurred after the tunnel's completion and handover to the Owner and the subsequent case is interesting as it illustrates the problems of courts dealing with 
geotechnical terminology; furthermore, the case is reported in the public domain, so the findings can be examined and reviewed.

The main sources of information that have been used in developing this case record are the opinion of the outer house (Woolman 2016) and those of the first division, inner house (appeal) (Carloway 2018; Menzies 2018; Glennie 2018). There has been no access to the numerous expert reports produced for the trial for the plaintiff SSE (the "Pursuer") or for the Defendant, Hochtief. Quotations from the experts are taken from Woolman's opinion (2016) without identifying their Clients. This is deliberate, as the duty of experts is to the court and not to their Clients. The main source of factual information is the first opinion by Lord Woolman favouring the Contractor. In appeal, the Lord President, Lord Carloway supported the opinion of Lord Woolman (for the Defendant) but this was overturned by the opinions of two of the three appeal judges (Lords Menzies and Glennie) who supported the Pursuer's position. According to current news reviews (e.g. New Civil Engineer, 6th June 2018), the case is set to be heard by the Supreme Court.

\subsection{Risk}

There is always risk associated with tunnelling, during construction and, later, in terms of operational performance. The concept of 'acceptable risk' is often used in geotechnics. For a risk to be as low as reasonably possible (ALARP), it must be possible to demonstrate that the cost involved in reducing the risk further would be disproportionate to the benefit, although it is unclear that that principle was adopted here for the Glendoe headrace tunnel. When deciding on using a tunnel boring machine (TBM), the decision needs to be taken, early on, as to whether to line the tunnel fully or not. This depends upon the quality of rock expected and the risk that is to be accepted. Concrete ring segments can be erected in effect as part of a manufacturing system, locked into place behind the machine circumferentially and pushed against by the machine as it advances. The rings must be designed at an early stage to carry the predicted rock load. Where rock stand-up time is considered adequate, then more time can be taken to erect a liner in situ, to carry the load after the TBM has cut the rock, although there will be some risks involved. For such cases, the TBM design is simpler but a decision must be taken on how much load to design for (Terzaghi 1946).

The original concept for the Glendoe headrace tunnel was for a drill and blasted, shotcrete-lined tunnel apart from areas where a full in situ concrete or steel liner was required. Lord Carloway (2018) states at paragraph 22 that "In due course, the proposal to have a completely lined tunnel, which formed the basis for Part 6 (of the contract), was abandoned". It is noted that the design life of 75 years was in Part 6.3.2 of the contract according to Lord Carloway (paragraph 19, 2018); so presumably, this concept of design life was linked originally to the idea of a fully lined tunnel.

An alternative design by Finnish company, Pöyry Energy JV (Pöyry) for the Contractor, Hochtief, was proposed using a TBM for construction in the design-build contract. It was calculated that using this method, the tunnel could remain 60\% unlined (Class I) (Lord Carloway 2018, paragraph 23). The highest class of support envisaged (Class IV) shown in the Rock Excavation Classification of Hochtief, reproduced in simplified form here as Tables 1 and 2, was steel sets with shotcrete but this was not actually used. Class 3 , which was used for only $0.3 \%$ of the tunnel, according to Woolman (2016, paragraph 67), comprised $100 \mathrm{~mm}$ of shotcrete with steel mesh circumferentially and rock anchorages. The Rock Support Methodology, proposed by Pöyry was accepted by SSE.

The acceptance of risk of minor rock falls was high as is apparently normal for Norwegian unlined, hard-rock tunnels (Palmström and Berdal 1987). Broch (2000) states that:

"Most of the Norwegian hydropower tunnels have only $2-4 \%$ concrete or shotcrete lining; only in a few cases, has it been necessary to increase this to $40-60 \%$. The low percentage of lining is due not only to favourable tunnelling conditions-it is first and foremost the consequence of a support philosophy which accepts some falling rock during the operation period of a water tunnel. As long as rockfalls in certain parts of the tunnel do not occur frequently and increase the head loss, a reasonable number of small blockages spread out along the tunnel will not harm the tunnel or disturb the operation of the hydro power station."

A major geotechnical question follows: whether a tunnel with smooth, 'rifle bore' sides as produced by TBM presents a lower, long-term risk of wedge failure compared to an irregular tunnel formed by drill and blast in the same rock mass. It is evident that drill and blast construction exposes and emphasises weak areas and discontinuities as overbreak zones and that such weak zones are far less evident in TBMconstructed tunnels - but does this represent a reduced risk in the long term? In the case of the Glendoe headrace tunnel, the lining requirement was reduced from a predicted $100 \%$ by Jacobs for a drill and blast tunnel, to less than $1 \%$ for the as-constructed tunnel, using a TBM, albeit that this was no doubt partly on the basis of hydraulic roughness. One of the tunnelling experts, Professor Grøv noted that “... mapping a TBM tunnel is a difficult exercise. Because of its smooth surface 'details may get lost'" (Woolman 2016, paragraph 174). It must be concluded that, whilst an observer might judge the risk of rock fall in a drill and blast tunnel more severely than the same risk in a TBM-bored tunnel, in the 


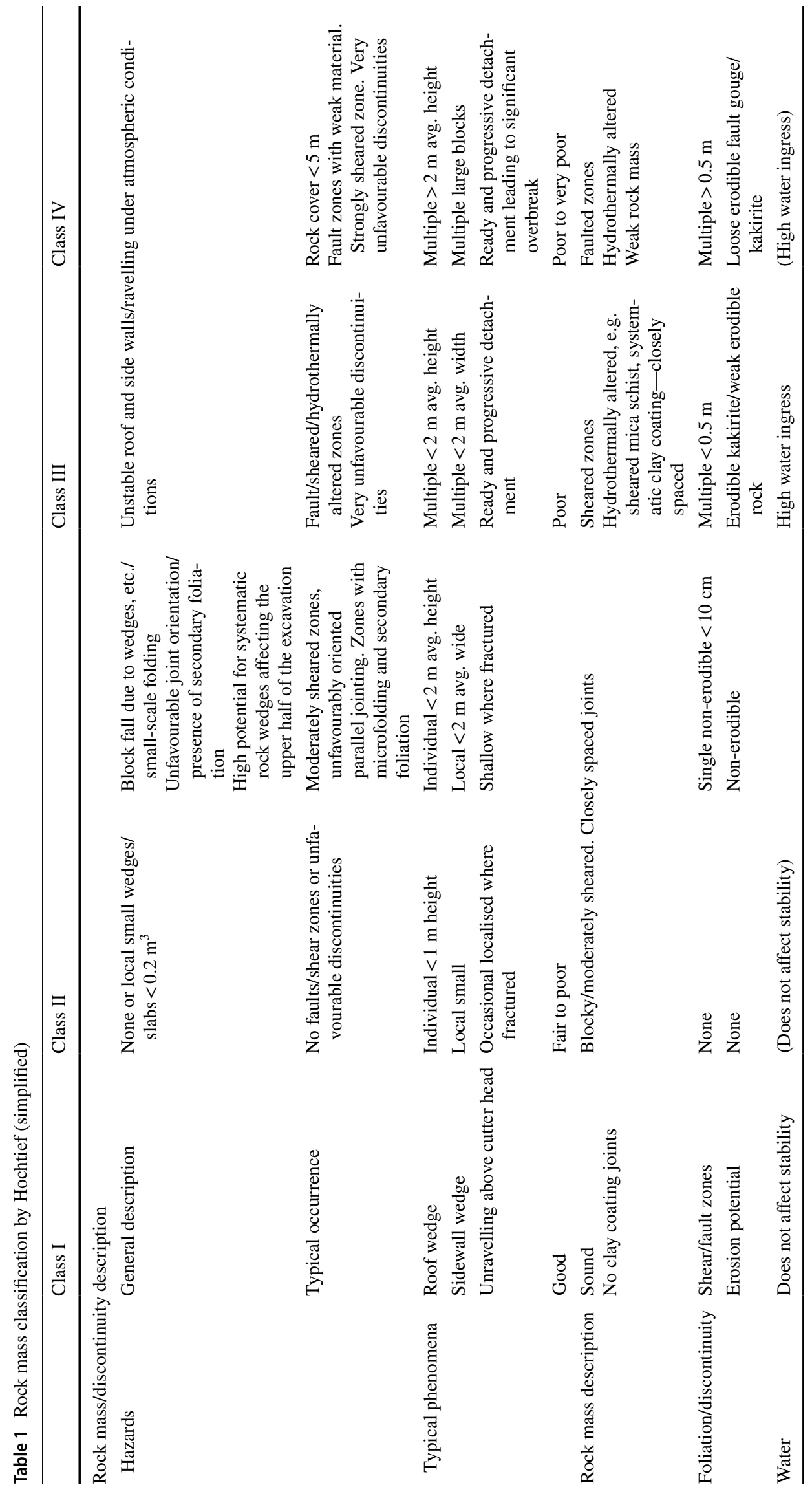


Table 2 Support category of Hochtief (simplified)

\begin{tabular}{|c|c|c|c|c|}
\hline Support category & Class I & Class II & Class III & Class IV \\
\hline Description & $\begin{array}{l}\text { No support, or spot bolting } \\
\text { and/or local shotcrete in } \\
\text { the roof }\end{array}$ & $\begin{array}{l}\text { Systematic support upper } \\
120^{\circ}\end{array}$ & \multicolumn{2}{|c|}{ Systematic support over full perimeter } \\
\hline Shotcrete & $50 \mathrm{~mm}$ if required & $\begin{array}{l}\text { Upper } 120^{\circ} 50-80 \mathrm{~mm} \text {, wire } \\
\text { mesh. }\end{array}$ & $\begin{array}{l}100 \mathrm{~mm}+\text { wire mesh, full } \\
\text { periphery }\end{array}$ & $\begin{array}{l}200 \mathrm{~mm}+\text { wire mesh, full } \\
\text { periphery }\end{array}$ \\
\hline Bolt & Spot, $22 \mathrm{~mm} \emptyset, L=2.2 \mathrm{~m}$ & $\begin{array}{l}1.4 \mathrm{~m}(\text { radial }) \times 1.86 \mathrm{~m} \\
22 \mathrm{~mm} \emptyset, L=2.2 \mathrm{~m} \text { stag- } \\
\text { gered } 4-3-4, \text { etc. }\end{array}$ & $\begin{array}{l}1.1 \mathrm{~m} \text { radial } \times 0.93 \mathrm{~m} \\
22 \mathrm{~mm} \emptyset, L=2.2 \mathrm{~m} \text { stag- } \\
\text { gered } 8-7-8, \text { etc. }\end{array}$ & $22 \mathrm{~mm} \emptyset, L=2.2 \mathrm{~m}$ if required \\
\hline Ribs (if required) & None & None & None & Ribs $1-1.25 \mathrm{~m}$ \\
\hline Options & A & $\mathrm{A}, \mathrm{E}, \mathrm{F}$ & $\mathrm{A}, \mathrm{B}, \mathrm{D}, \mathrm{E}, \mathrm{F}, \mathrm{L}$ & $\mathrm{B}, \mathrm{C}, \mathrm{D}, \mathrm{F}, \mathrm{G}, \mathrm{H}, \mathrm{I}, \mathrm{J}, \mathrm{K}, \mathrm{L}$ \\
\hline A & \multicolumn{4}{|c|}{ Increase application of shotcrete, extension of application of shotcrete. } \\
\hline B & \multicolumn{4}{|c|}{ Bolts below springline (by separate drilling equipment) } \\
\hline $\mathrm{C}$ & \multicolumn{4}{|l|}{ Additional bolts } \\
\hline $\mathrm{D}$ & \multicolumn{4}{|c|}{ Increase capacity and length of bolts (e.g. $32 \mathrm{~mm} \varnothing$ ) } \\
\hline $\mathrm{E}$ & \multicolumn{4}{|c|}{ Bolted U-shaped profile for upper $120^{\circ}$} \\
\hline $\mathrm{F}$ & \multicolumn{4}{|c|}{ Hydraulic activation of cutterhead shield support } \\
\hline $\mathrm{G}$ & \multicolumn{4}{|l|}{ Forward probing } \\
\hline $\mathrm{H}$ & \multicolumn{4}{|l|}{ Pressure relief drillholes } \\
\hline I & \multicolumn{4}{|c|}{ Forward compensation grouting } \\
\hline $\mathrm{J}$ & \multicolumn{4}{|l|}{ Stronger steel arches } \\
\hline $\mathrm{K}$ & \multicolumn{4}{|l|}{ Spiles } \\
\hline $\mathrm{L}$ & \multicolumn{4}{|l|}{ Monitoring } \\
\hline
\end{tabular}

Fig. 6 Section along the headrace tunnel, showing location of Conagleann Fault Zone where the collapse occurred. (traced from Dr. Smith's presentation to court, slides 5 and 7, Woolman 2016)

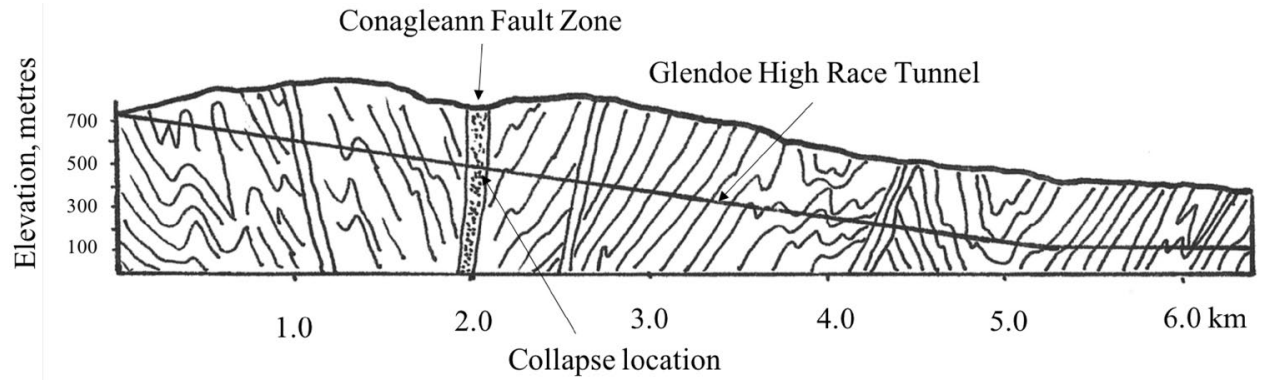

longer-term, under operation, the risks will be essentially the same.

Eight months following the satisfactory completion of the tunnel and handover of the tunnel from the contractor to the owner, a large-scale collapse occurred although there are indications that the tunnel was collapsing throughout that period. The tunnel was blocked over a long section and the Owner took the decision at some stage later to construct a diversion tunnel which was eventually built by drill and blast by a 2 nd contractor, Bam Nuttall. It was decided to fully line this diversion tunnel with a 500-mm secondary concrete waterproof lining. Furthermore, a 100-mm-thick 'concrete' lining was applied, in retrospect, to about half the length of the headrace tunnel that had already been constructed by Hochtief (Appleyard 2012). This decision to line a tunnel that was originally constructed as essentially unlined expresses either the adoption of a reduced level of risk by the Owner in hindsight or a more realistic appreciation of the hidden hazards in the TBM-constructed walls.

\subsection{Geological Conditions in the Headrace Tunnel}

The geology of the headrace tunnel which was $6.2-\mathrm{km}$ long was set out broadly in Lord Woolman's opinion, in particular in a cross section, that was taken from Dr. Smith's (British Geological Survey, "BGS") presentation to the court (Fig. 6). The BGS reports that these rocks are a series of Pre-Cambrian, folded and faulted, metamorphosed mudstones and sandstones. Figure 6 shows a major fault, the Conagleann Fault Zone (CFZ)_mapped at the surface and extrapolated downwards and predicted 
Fig. 7 Rock Excavation Classification sheet for chainages 2117-2101, copied from Carloway (2018), Appendix 5, page 137. Description reads: "Some shear zones with QMS kakerite, local slab formation and blockfall in sidewalls. Rotate CII support to LHS (left hand side) from $\mathrm{CH} 2117$ to 2107. Extend shotcrete to maximum extent in shotcrete bay and backfill voids". Note that the boxes dealing with erosion potential are ticked as "Single Non-erodible $<10 \mathrm{~cm}$ " and "None". The sheet is signed as Prepared by D. Taylor (23/8/07), Confirmed (uncertain who for) by J. Ager (18/9/07) and Approved for SSE by D. Williams (20/09/07)

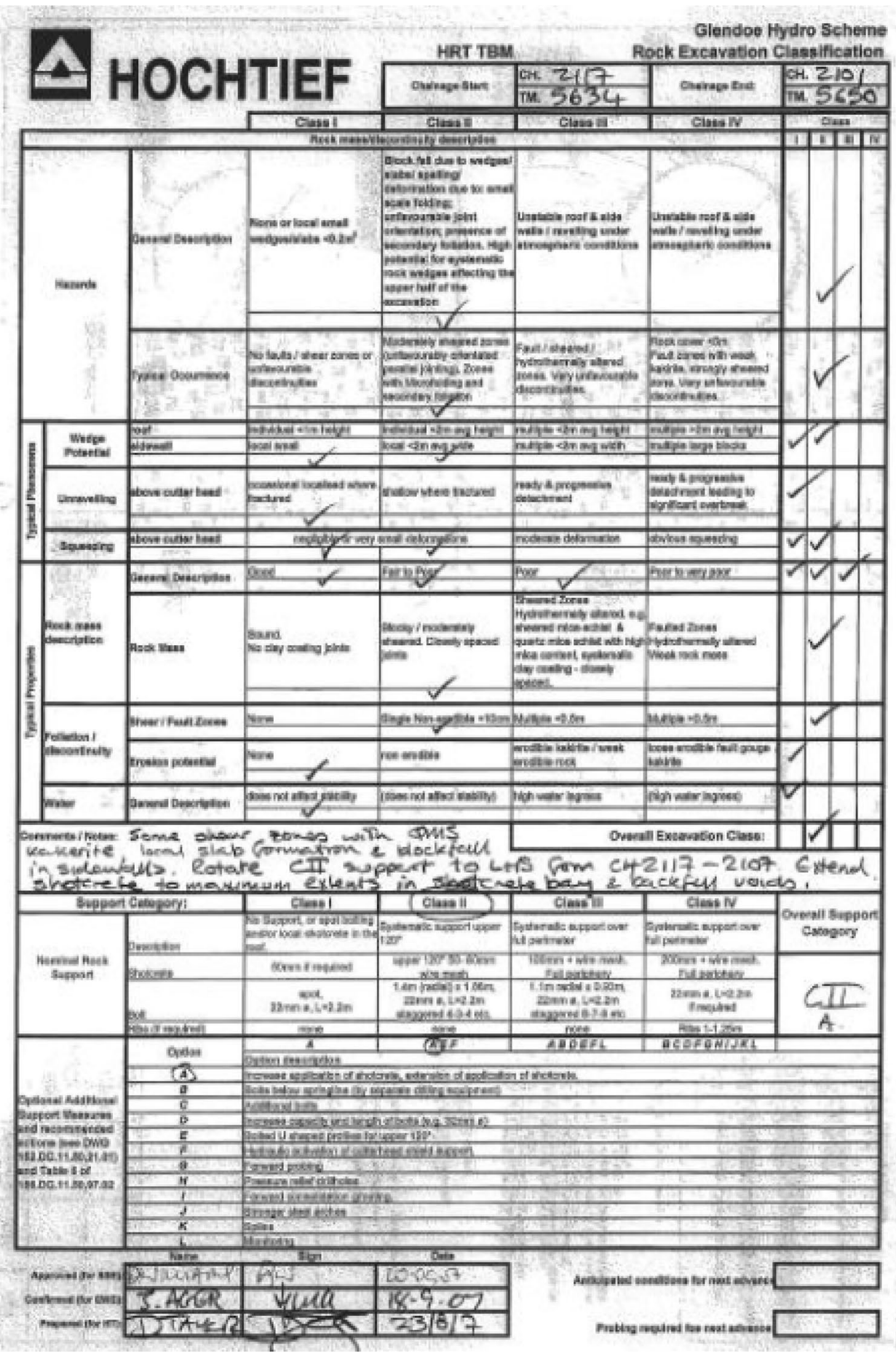

to be encountered between chainages 2040-2210 (170 m). The CFZ was anticipated as being hazardous and David Taylor, the engineering geologist of Hochtief, warned the TBM crew to take "extreme care" in that area of the tunnel (Woolman 2016, paragraph 70). In the event, Mr. Spiers, SSE's resident engineer recorded that the conditions were class 1 throughout: "The TBM has now passed through the predicted zone of the Conagleann Fault, but indications of its existence were imperceptible" (Woolman 2016, paragraph 71). Such mismatches between supposedly onerous faults, mapped at the ground surface, and conditions encountered in tunnels are not unusual (West 1983).

Throughout the tunnelling, geological conditions were mapped and the geotechnical classification applied by Taylor with his findings and the sheets submitted to the 


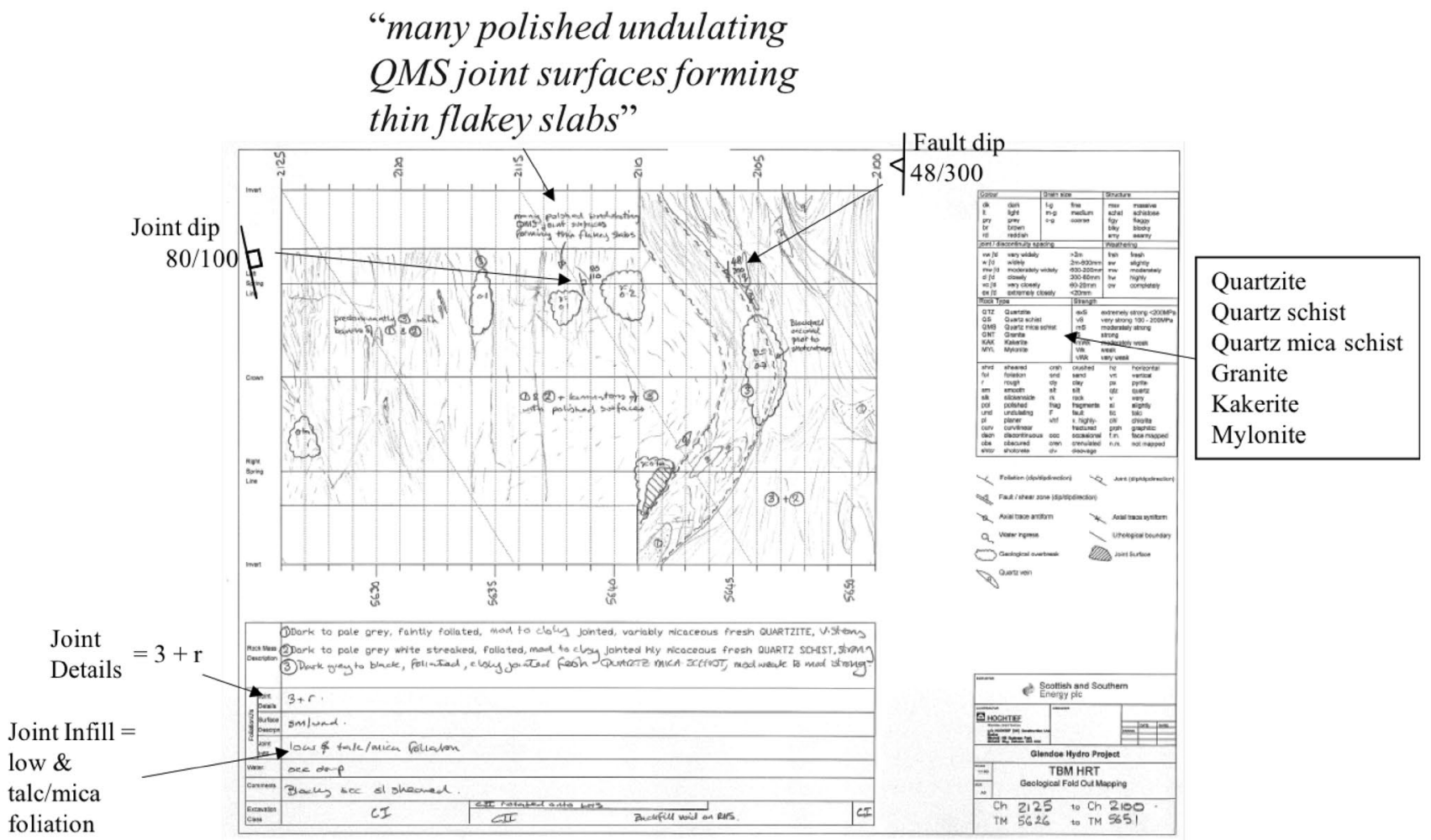

Fig. 8 Part of section where collapse occurred, from the Geological Fold Out Mapping Sheet for chainages 2025-2010, reproduced in Lord Carloway's Opinion at page 138. Note that the first two rock names are typed (presumably typical), with just the strengths added in writing (very strong and strong). Rock type 3 is added, in writing, as "closely jointed fresh QUARTZ MICA SCHIST, moderately weak to moderately strong". Note also the comment at the top of the page

supervising engineering geologist of Jacobs (Derek Williams) for approval on behalf of SSE (Fig. 7).

'Geological Fold Out Mapping' sheets were produced on a 25-m basis and one of these was reproduced by Carloway (2018) as Appendix 6, page 138, and is presented here as Fig. 8. On this sheet, there was a table of terms to be used in description. This listed the Rock Types that could be encountered as:

\section{Quartzite \\ Quartz Schist \\ Quartz Mica Schist \\ Granite \\ Kakerite (sic) \\ Mylonite}

This table is clearly not a comprehensive list of geological terms and reflects a choice, specific for the tunnel. The last two terms were to be applied to faulted rocks.

Kakirite is not a term used in the Geological Society of London Field Guide on Mapping Geological Structures "many polished undulating QMS joint surfaces forming thin flakey slabs". This is the likely material that collapsed to form the fine pile of debris seen in Fig. 10. The two discontinuity directions 48/300 in the fault zone and 80/110 in the general rock, form an adverse wedge with a third joint dipping, say, at 70/200. Note that "Joint Details" are defined as " $3+r$ ", meaning three joint sets plus random joints, for the Q-system

(McClay 1987) or even in the Penguin Dictionary of Geology (Whitten and Brooks 1972) and is not used in fault rock classification in the UK (Sibson 1977; Woodcock and Mort 2008). Where the term is used, in Switzerland and elsewhere, the rock is typically equivalent to Fault Breccia and Gouge in the UK. The material is sometimes unconsolidated and weak, but it can be cemented with secondary minerals such as calcite or quartz.

The term 'mylonite' was probably used to include 'cataclasite', both of which are cohesive, fault rocks.

\subsection{Geotechnical Conditions}

Jacobs, who were employed by SSE to complete the site investigation studies, to "prepare the client's design", and to supervise the works, according to Reynolds (2017), anticipated $97.5 \%$ of the excavation to be in 'good' rock (Woolman 2016, page 9). According to Lord Carloway (2018, paragraph 29), Pöyry anticipated $68.7 \%$ to be Class I, $23.8 \%$ to be Class II, $6 \%$ to be Class III and $1.5 \%$ to be Class IV in their design of 2004. 
According to Lord Woolman (2016, paragraph 67), Hochtief in the excavated tunnel, "found the tunnel to be very dry and the rock mass conditions much better than predicted". Lord Woolman lists the Classes of expected support vs. as-built, as follows: Expected As Built

$\begin{array}{llc}\text { Class I } & 58.9 \% & 84.3 \% \\ \text { Class II } & 23.1 \% & 15.4 \% \\ \text { Class III } & 14.3 \% & 0.3 \% \\ \text { Class IV } & 3.7 \% & 0 \%\end{array}$

Whatever the numbers, it is clear that conditions were found to be unexpectedly good in the tunnel compared to conditions predicted from ground investigation, prior to the works, although the ground investigation data and interpretation are not presented in the opinions of the four Lords.

The terminology adopted in the Hochtief Rock Excavation Classification and Risk Assessment sheet is set out in Tables 1, 2 and 3, which have not been criticised as incorrect or inadequate by any party to my knowledge. Tables 1 and 2 addressed the support to be provided for rock masses of different qualities. For faulted rock, under Class II (fair to poor rock), in the row beginning "Foliation/discontinuity" it says, "Single Nonerodible $<10 \mathrm{~cm}$ ". Another potential hazard, included under Class II is "High potential for systematic rock wedges affecting the upper half of the excavation". In the row headed "Foliation/ discontinuity", Class III (poor rock) includes $<0.5 \mathrm{~m}$ of "erodible kakirite/weak erodible rock" and Class IV (poor to very poor rock) includes multiple layers of "loose erodible fault gouge/kakirite" of greater than $0.5-\mathrm{m}$ thickness.

According to Woolman (2016, paragraph 43), SSE approved Pöyry's detailed design before construction began. This included the 'Headrace TBM Excavation Rock Support Methodology ('RSM')' including Table 3 (which is part of the original Table 11 that was agreed by all parties as part of the rock support system) that addresses 'risk'. In the case of encountering "erodible kakerite" (Classes III and IV), a highrisk situation (9) would be made low risk (3) by the application of shotcrete, thereby reducing the likelihood rating from 3 to 1 .

Interestingly, in Table 3, the risk of wedge failure was considered relatively low: "Risk is judged as generally low in bolted and shotcreted parts. Locally detachments possible: risk increased/high in unsupported parts" and this was to be mitigated by "Slow rate of impoundment; regular pattern of drainholes in shotcreted areas".

\subsection{The Operations}

The tunnels and power station were taken over by the Project Manager Neil Sandilands of SSE on 18 December 2008 as "sufficiently complete for safe operation" (Woolman 2016 paragraph 79).

There are patchy details recorded on the operations in Woolman (2016, paragraphs 89-95). There were apparently 1700 sensors installed to monitor 'every aspect of operation' but these were reduced to 179 for fear of overwhelming the engineers, 140 with audible alarms (Woolman 2016, paragraph 86). According to the same paragraph, "the scheme will automatically shut down if they detect a critical fault"but did not do so, apparently, prior to the eventual massive rock collapse following an 8-month history of indicative factors. In 2009, there were no alarms for needle valve opening, net head, or head loss (Woolman 2016, paragraph 33). There is no further mention of the sensors in the opinions of the Lords.

The scheme was handed over in December 2008, but the first mention of operations in Lord Woolman's report, after acceptance by the National Grid in January 2009, which was "undertaken by Andritz using its own specialist instruments", was in "late May or early June 2009" when Sandilands "noticed" a head reading of $584 \mathrm{~m}$ (Woolman 2016, paragraph 89). The net head at Glendoe was designed to be between 600 and $606 \mathrm{~m}$ (Woolman 2016, paragraph 31).

Sandilands stated that "failure was not in my mind at all, this was a brand new hydro scheme" (Woolman 2016, paragraph 89). There was then a litany of records (what was the process of recording?) including "unusual thumping noises" over a period of $2 \mathrm{~h}$ on 30th June, culminating in Sandilands and Wallace of Hochtief noting a "sediment plume" discharge 5 weeks later, on 4th August, but this fact (indicating some kind of collapse or erosion at the very least), was not investigated. It would be interesting to know more about the operations. How many times was the system powered up over the 8-month period? What was the system of record keeping?

\subsection{Precedent}

Previous collapses that occurred in 1990, in an 'unlined', unpressurised tunnel, owned by Scottish Hydro-Electric (SHE) were dismissed as irrelevant by Lord Woolman (2016, paragraphs 23 and 24) -all tunnels having their own issues, and the case is not raised again by the appeal judges.

However, the 1990 collapse was in unlined tunnels constructed through Scottish, metamorphic, faulted rocks, as at Glendoe, and was written up in a paper published by the Institution of Civil Engineers, UK, by Cameron and Sandilands (1996). The case is worth examining in some detail, not least because N. Sandilands is presumably the same person who figures extensively in the Glendoe case that started in 2004, as project manager of SHE, later SSE. As noted earlier, Sandilands "sometime in late May or early June 2009 " noticed a very low net head reading of $584 \mathrm{~m}$ in the 


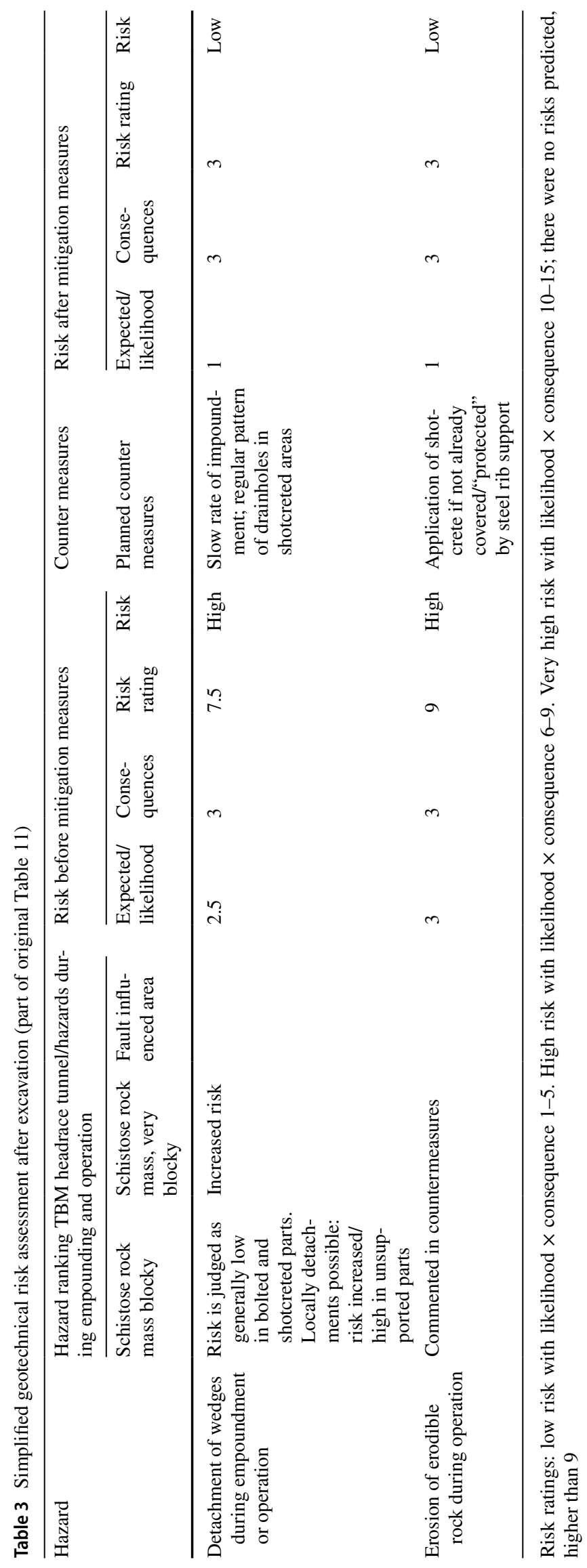


tunnel. His colleague Brian Still said that it was probably a calibration error, which Sandilands accepted because he "did not have failure in his mind at all" (Woolman 2016, paragraph 89). On this statement hangs a lot, regarding the risk that was allocated to the Contractor and the risk that was accepted by SSE.

One might accept this at face value if Sandilands had not been involved in the previous failures and reparatory works at North Lochay. In that case, when an overflow occurred at a major intake, the tunnel was dewatered. On inspection, two major collapses were found: one of $1000 \mathrm{~m}^{3}$, the other of $200 \mathrm{~m}^{3}$ together with 32 other significant rock falls throughout the tunnels. Both of the major collapses occurred where concrete arches had been used (not tied together) to support the rock mass. The tunnels were by then 40 years old, but nevertheless, the risk of using unlined or poorly supported tunnels was obvious. Following the more than 30 rock fall failures at North Lochay, the authors, Cameron and Sandilands, were asked questions regarding the geological assessment (Cameron and Sandilands 1997):

Questions by T. H. Douglas and T. J. M. Patterson (Mott Macdonald): "Both the major rock falls occurred where faults intersected or were in close proximity. Were the faults or any other potential problems in the roof fall areas noted during geological logging carried out at the time of construction?"

Answers: "The original geological logs show the fault" and "The original geological records were found to be both adequate in scope and accurate" and "As discussed previously, more rigorous inspections are now being carried out and a consultant geologist is retained".

It would have been anticipated that, following this experience published in ICE, the Project Manager would have had rockfalls directly in mind, unless he was satisfied that the smooth tunnel, constructed by the TBM, had no potential to collapse. If the Owner of a scheme, despite knowledge of the risk involved, selects an unlined tunnel scheme, for a highly pressurised headrace tunnel of more than 6-km length, then so be it. This is apparently the case at Glendoe where a bid for an unlined tunnel constructed by TBM was accepted as an alternative to a drill and blasted, fully lined tunnel.

\subsection{The Extent of the Collapse}

Lord Woolman's opinion on the extent of the collapse are, he acknowledged, "pure guesswork" (Woolman 2016, paragraph 150) as are the causes, in that there was no investigation carried out of the collapse and the blocked section of tunnel remains blocked. The blocked off length of tunnel was originally thought to be $270 \mathrm{~m}$ (Woolman 2016, paragraph 110) but was later established by an electronic theodolite to be $71 \mathrm{~m}$ (Woolman 2016, paragraph 143). A volume of $1394 \mathrm{~m}^{3}$ collapsed rock can be calculated to be within the blocked tunnel section (cross-sectional area $\times 71 \mathrm{~m}$ ). The amount of collapsed material is estimated as somewhere between 2374 and 13,000 $\mathrm{m}^{3}$ (Woolman 2016, paragraph 150). The balance of the smallest volume is $1480 \mathrm{~m}^{3}$ which must be partly, or fully, distributed in the $600 \mathrm{~m}$ of debris, running down the tunnel towards the turbines (Woolman 2016 , paragraph 109). If the collapse was $13,000 \mathrm{~m}^{3}$, then a large proportion of this collapse would remain above the blocked length of tunnel. The shortest length of the actual collapse zone was estimated at $8-10 \mathrm{~m}$ of tunnel by Dr. Büchi and $71 \mathrm{~ms}$ according to Professor Sloan (Woolman 2016, paragraph 150). Figure 9 illustrates the collapse, based on these estimates, the length of debris outrun and pictures of the debris. It is calculated that the collapsed rock might extend up to between 110 (Büchi) and 172 (Sloan) m above the tunnel (more than half way towards the ground surface) (Fig. 10).

\subsection{The Causes of the Collapse}

Lord Woolman in his opinion (Woolman 2016) finds that it is impossible to determine the cause of collapse and supports Dr. Büchi's generalised view that it was a "geological accident" (paragraph 151).

He argues that the most likely explanation of the collapse was, essentially, "the deterioration of thin single shears" when submerged, "by slaking", "between good rock in between" (paragraph 152) followed by progressive collapse, dominated by erosion. This theory relies on 'slakeable' material being present (of which there is no evidence) and 'erodible rock' being present, again of which there is very little evidence. Slakeability is a term that is used to define completely weathered rock; highly weathered rock (soil) does not slake, by definition (Anon 1995). This mechanism of failure was adopted by all three Appeal Lords, without question.

There are other factors to be considered as listed in Table 4. Firstly the 'slaking theory' needs to be addressed.

According to Lord Carloway (2018) (paragraph 54) Professor Sloan stated that:

"The defenders had identified erodible rock in shear zones within this fault, but they had failed to support and protect them in the manner required by the works information and design. The defenders' failure to install sufficient support had been directly responsible for the collapse."

and at paragraph 58:

"There had been a significant amount of erodible rock in the collapsed zone." and that "The works information and design required every shear zone to be sup- 
Fig. 9 Interpretations of debris volumes and dimensions at Glendoe tunnel collapse. a Shows an interpretation of a rock fall of $2874 \mathrm{~m}^{3}$, blocking off $71 \mathrm{~m}$ of tunnel, with the rest of the debris stretching out $600 \mathrm{~m}$ towards the turbines. It is assumed that this is for a block fall from the roof, of dimensions $10 \mathrm{~m} \times 5 \mathrm{~m}$. The rock would have fallen from a void extending $172 \mathrm{~m}$ above the tunnel invert. b Shows an interpretation of an alternative model with collapse throughout the $71 \mathrm{~m}$ and debris up to $13,000 \mathrm{~m}^{3}$. For this scenario, there would remain debris to a depth of about $85 \mathrm{~m}$ above the tunnel invert and voided ground up to $110 \mathrm{~m}$. For both models, there is comminuted, disintegrated debris blocking the upper part of the headrace tunnel (see Fig. 10 plus Sect. 4)

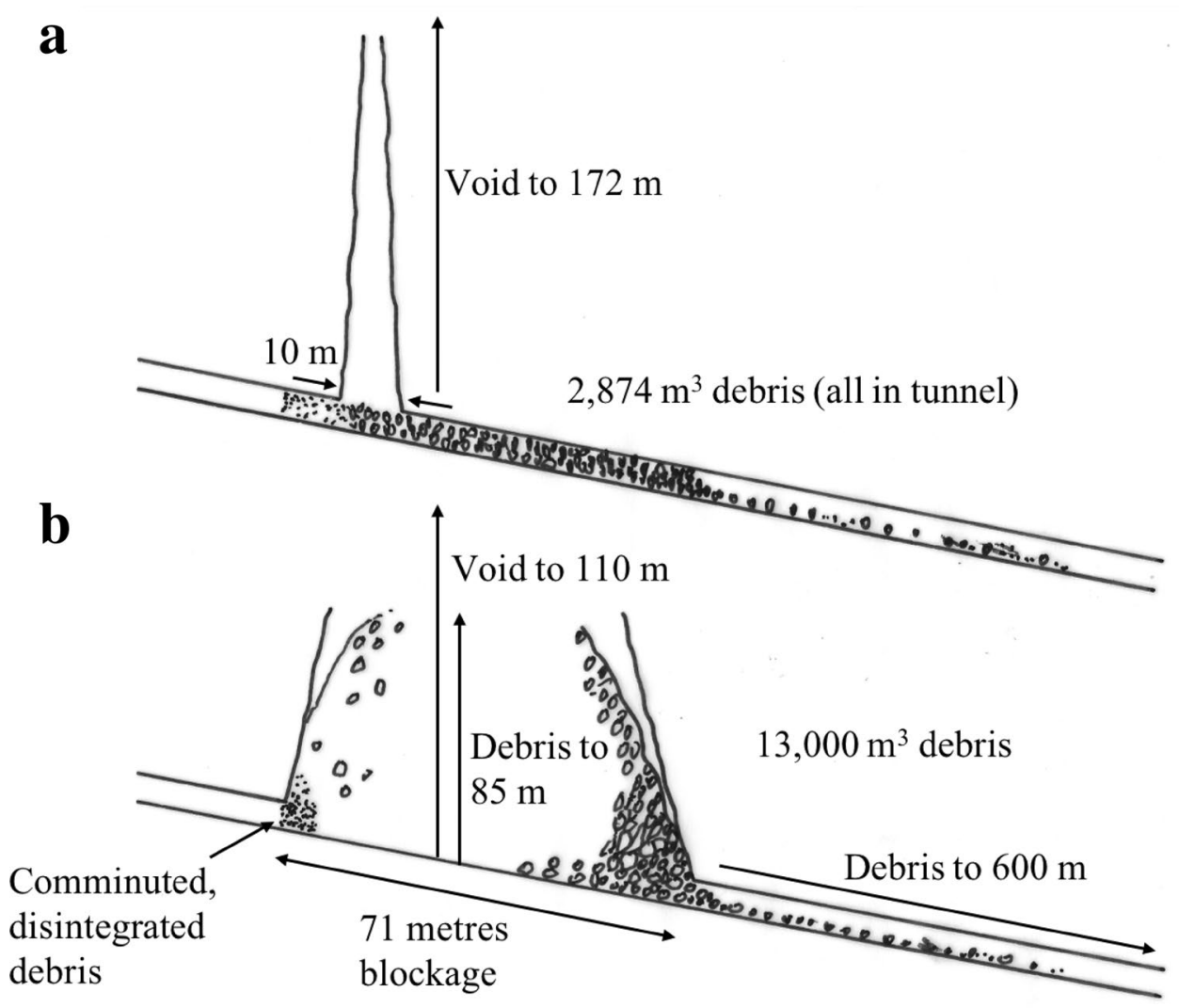

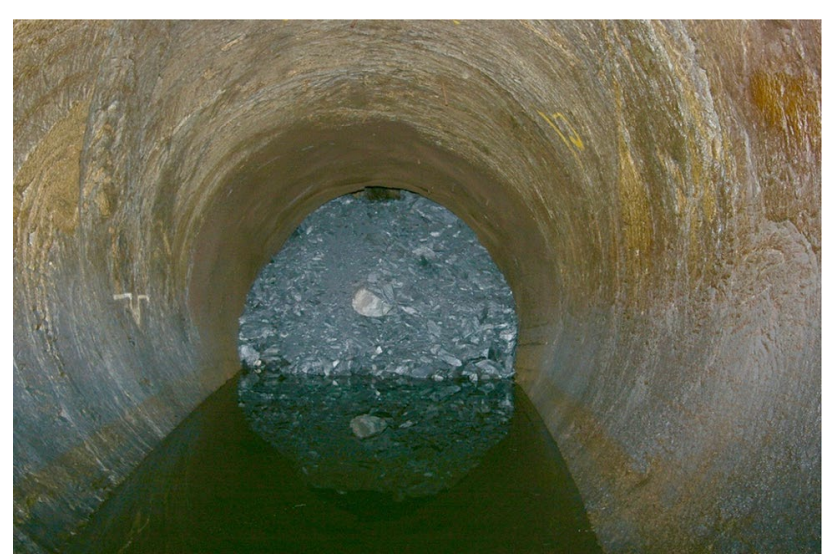

Fig. 10 Collapsed ground (upstream end) - taken from Woolman (2016). Note folded and faulted rock in the walls of the tunnel. This must be close to the fault zone. Note that the rock mass is broken down to very fine material, which is remarkable, given the decision not to line this section, and that no one could see the fault. The interpretation is that the material in situ was disintegrated, probably by tectonic action, rather like the 'Rashings' material in the South Wales Coalfield which looks intact but on extraction breaks down to sigmoidal fragments

ported by the application of shotcrete over the full perimeter, as the minimum class III support." and at paragraph 61 he continues:

"At chainages 2117-2101, there had been evidence of faulting, using the criteria of erodible rock. The REC had mentioned kakirite and erodible rock over quite a length. This had not been reproduced in the mapping. The REC sheet findings indicated class III."

Much of Professor Sloan's evidence cannot be confirmed from the information in the public domain. Fortunately, however, the last statement can be checked. Lord Carloway (2018) includes in his opinion the Geological Mapping Sheet for chainages 2125-2100 at Appendix 5 and the Rock Excavation Sheet for Chainages 2117-2101 at Appendix 6. Reading these records, reproduced here as Figs. 7 and 8, there is no mention of erodible rock (just QMS Kakerite), nor "over quite a length". The word "erodible" is missing from the Rock Excavation Classification (REC) sheet and from the Mapping Sheet. The boxes ticked on the REC indicate Class 1 support conditions, not Class III.

It needs to be repeated that the word kakirite does not equate to 'erodible', and Class II might have more clearly specified 'non-erodible kakirite' to distinguish this from the 'erodible kakirite' in Classes III and IV in Table 1.

The engineering geologist David Taylor (of Hochtief) noted the presence of Quartz Mica Schist Kakerite-presumably meaning 'fault breccia'. He describes this on the 
Table 4 Evidence regarding causes of collapse

\begin{tabular}{|c|c|c|c|}
\hline Hazard & $\begin{array}{l}\text { Evidence in Geological Fold Out Map- } \\
\text { ping sheet (Fig. 8) }\end{array}$ & $\begin{array}{l}\text { Evidence on the rock excavation clas- } \\
\text { sification sheet (Fig. 7) }\end{array}$ & Other factors \\
\hline Erosion & Absent & $\begin{array}{l}\text { "Some shear zones with QMS kakerite" } \\
\text { (sic) are noted on the REC. It does not } \\
\text { state 'erodible kakerite', and erodible } \\
\text { kakerite is not indicated on the Geo- } \\
\text { logical Fold Out Mapping Sheet } \\
\text { The row headed 'Foliation/discontinu- } \\
\text { ity' is ticked under Class I-meaning } \\
\text { 'none' } \\
\text { There is no tick in the box indicating } \\
\text { 'erodible kakerite' (Class III) }\end{array}$ & $\begin{array}{l}\text { Samples were taken by Professor Broch } \\
\text { at almost all locations where poten- } \\
\text { tially erodible rock had been identified } \\
\text { (Woolman 2016, paragraph 75). Samples } \\
\text { were tested at the Norwegian Techni- } \\
\text { cal University and showed no signs of } \\
\text { slakeability }\end{array}$ \\
\hline Wedge failure & $\begin{array}{l}\text { Two discontinuity measurements were } \\
\text { taken, one for an evident fault zone } \\
\text { in excess of } 1.5 \text { m in thickness. Dip } \\
\text { is } 48 / 300 \text {. There is collapse of } 0.7 \mathrm{~m} \\
\text { depth, several metres laterally, associ- } \\
\text { ated with the fault in the crown of the } \\
\text { tunnel. The rock in the fault zone is } \\
\text { described as "Fresh QMS" but strength } \\
\text { is only "moderately weak to moder- } \\
\text { ately strong", which means strength as } \\
\text { low as 5-50 MPa. Rock of 5-12.5 MPa } \\
\text { can be broken by hand and is very } \\
\text { 'weak' for rock otherwise described as } \\
\text { 'fresh' } \\
\text { The } 2 \text { nd discontinuity measurement } \\
\text { is recorded as } 80 / 110 \text {. The adjacent } \\
\text { rock is described as "many QMS joint } \\
\text { surfaces forming thin flakey slabs". } \\
\text { 'Thinly' equates to } 60-200 \text { mm } \\
\text { For a critical wedge to be formed, a third } \\
\text { joint dipping at perhaps } 70^{\circ} \text { dipping } \\
\text { in a } 200 \text { direction is required. There is } \\
\text { no such joint recorded on the sheet but } \\
\text { there are traces in that direction and the } \\
\text { 'joint details box' (for the Q-system) } \\
\text { states three sets plus random, which } \\
\text { means that there were other joints } \\
\text { present than the two measured }\end{array}$ & $\begin{array}{l}\text { Most of the boxes are ticked as Class II, } \\
\text { including the hazard of "High potential } \\
\text { for systematic rock wedges affecting } \\
\text { the upper half of the excavation"-in } \\
\text { hindsight, this hazard might have been } \\
\text { dealt with best by full lining }\end{array}$ & $\begin{array}{l}\text { The two photographs presented as Figs. } 10 \\
\text { and } 12 \text { show very different conditions } \\
\text { Figure } 10 \text { shows the rock mass com- } \\
\text { minuted to fine debris as if from a } \\
\text { rock burst. This is a photograph of the } \\
\text { upstream end. Figure } 12 \text { shows large } \\
\text { blocks of irregular rock that have fallen } \\
\text { from the roof, downstream } \\
\text { The size of the collapse, stretching } \\
\text { away from the tunnel by estimates that } \\
\text { range up to } 172 \text { m means that it is best } \\
\text { explained as progressive collapse of rock } \\
\text { wedges }\end{array}$ \\
\hline
\end{tabular}

Mapping Sheet as "many polished undulating QMS joint surfaces forming thin flakey (sic) slabs".

Professor Broch visited "practically all" the locations described by Pöyry (the designer) and took samples to check for swelling clay minerals which would make the rock moresusceptible to slaking (Woolman 2016, paragraph 75). Tests conducted at the Norwegian Technical University did not indicate any potential problems due to swelling.

In my opinion, there is far more evidence of the collapse being dominated by large-scale wedge failure and rock collapse on incipient discontinuities than by erosion. In Table 4, I list some of the factors. Firstly, there are the discontinuity measurements in Fig. 8. The two measurements of 48/300

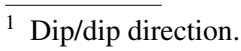

(for a fault zone rock that is moderately weak to moderately strong, meaning 5-50 MPa) and of 80/100 taken in the area of sheared QMS require just one more discontinuity dipping at, say (precision not required), 70/200 to form an unstable wedge as shown in Fig. 11. It is noted that Taylor classified the jointing as " $3+r$ ", which translates to three sets plus random joints in the $Q$ classification (Barton et al. 1974). Two 'sets' (measurements) are recorded, but where is the third? There are possible traces in Fig. 8 with the correct orientation but the traces die out, presumably as incipient discontinuities. Secondly, there is a photograph of large blocks of rock from the downstream end of the debris, reproduced here as Fig. 12. It is probable that the failure was the result of the falling of large wedges of rock, released by discontinuities, over a period of 6-8 months, leading to the collapse of rock up to 110-172 $\mathrm{m}$ above the tunnel as depicted in Fig. 9. 


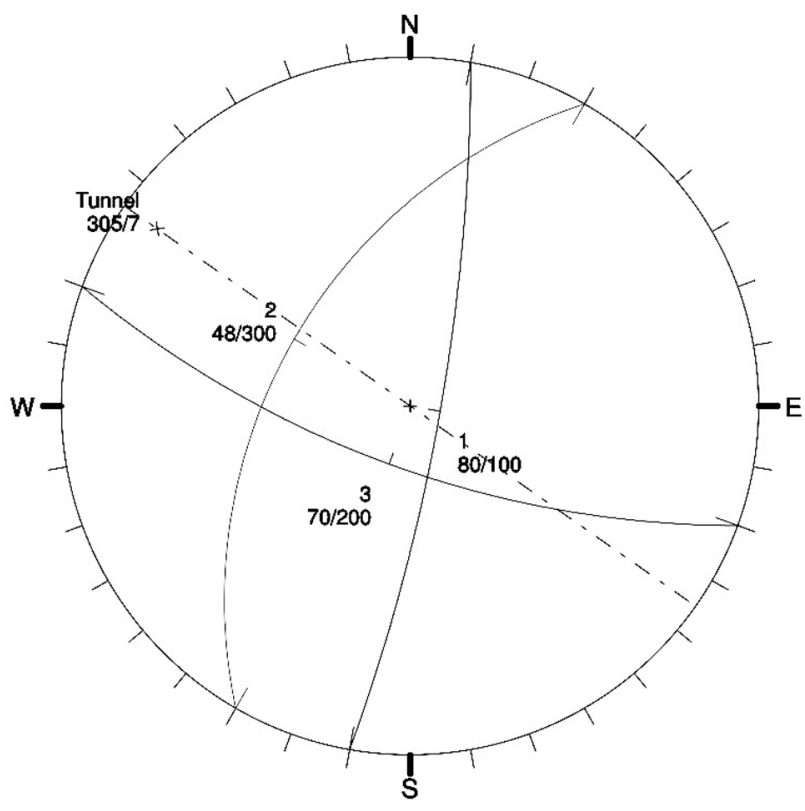

Fig. 11 Stereogram of tunnel in 305 direction, plunging at about $7^{\circ}$ with two discontinuities $48 / 300$ and $80 / 100$ (as measured in the Geological Mapping Sheet, in Fig. 8) and a hypothetical third joint (70/200). The three discontinuities produce an unstable wedge in the crown of the tunnel. Note that Taylor classified the rock as " $3+r$ " meaning three sets plus random. Stereogram produced by software UNWEDGE by Rocscience, Canada

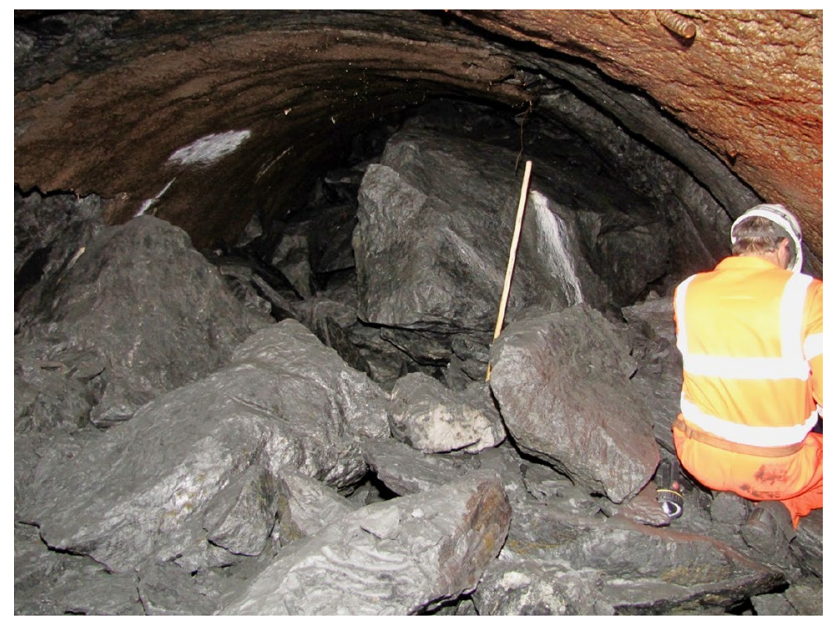

Fig. 12 Collapsed ground (downstream end). Note that the ground is largely made up of large fallen blocks (according to this photo). Photograph from Woolman (2016)

Considering the scale of mapping and logging, metre-bymetre, the opportunity to visibly assess, globally, the faulted rock mass over tens of metres was evidently lacking, despite the best intentions of all parties.

At the upstream end of the tunnel blockage, the rock is comminuted to small pieces as seen in Fig. 10. The rock could not have travelled far to become broken up. It has not been abraded by flowing water. It must have been exposed in the walls of the tunnel as ostensibly intact rock that has been broken down, possibly by rock fall-out on incipient discontinuities.

As Lord Woolman (2016) describes the situation at paragraph 180: "Many experienced tunnellers scrutinised the HRT both during and after the TBM drive. They included engineering geologists, tunnel designers, engineers and the TBM crew. They were actively looking for problems. None of them saw signs of faults that might threaten tunnel stability. None recommended the installation of a higher level of support at particular locations".

Lord Carloway in his Appeal opinion (2018) reports that Pöyry had only inspected part of the tunnel and not the collapsed zone (Ch2121-Ch2050) but there seems little doubt that the zone which collapsed had been adequately inspected and examined by many experienced professionals.

Lord Carloway (2018) concludes at paragraph 148 that "There was a prime facie case, based on a combination of the mapping and REC sheets, that Class IV support ought to have been installed". That opinion appears to be incorrect, and an example of a legal judgement, in hindsight, attempting to over-ride the opinions of professional engineers and engineering geologists, working in the tunnel at the time. Those engineering geologists and engineers were working to an approved system which accounted for localised behaviour, over a few metres length of tunnel, but, in my opinion, failed to account for much larger wedges. In hindsight, there is no doubt that the tunnel could have been made safe if it had been completely lined, at a cost, but that is a fundamental failure of the REC system, not the application of the REC to the tunnel which was applied diligently, and signed off by Derek Williams of Jacobs on behalf of SSE.

On 7th June 2011, the defendants referred the issue of responsibility for the collapse of the HRT to Adjudication. The adjudicator (Robert Galbraith QC) found that:

“...the rock support works as designed and constructed did not constitute a Defect for the purposes of Clause 11.2(15). It is true that a collapse subsequently occurred. However, that was not because there was a Defect for the purposes of the Contract. It occurred simply because there are inherent risks of rock falls and collapses in unlined tunnels. These are part of the risks that the Parties are aware of when the price is being negotiated. The incidence of such rock falls and collapses can be greatly reduced by using a fully lined tunnel, but this would cost far more than an unlined tunnel." (Carloway 2018, paragraph 51).

Dr. Wilhelm, giving evidence, explained that the shear zones must have been interconnected above the HRT, but he did not say that the collapse could have been anticipated 
(Carloway 2018, paragraph 204). Carloway continues: "The commercial judge listened to the pursuer's submission on precisely this point and made positive findings that nothing could have been seen in the tunnel". In my opinion, the fault structure, which collapsed to form a void extending up to $170 \mathrm{~m}$ above the tunnel crown and occupying a length of tunnel between 10 and $71 \mathrm{~m}$, was just too large to be recognised by the conscientious observers. The only way to ensure safety against collapse in such a tunnel is to use full periphery liners, of 500-mm thickness, as was done in the remedial, diversion tunnel constructed by Bam Nuttall.

\subsection{The Q-System}

At Glendoe, the Hochtief geologist, David Taylor, carried out studies, and then produced documents that were later "approved" on behalf of SSE by the consulting engineering geologist employed by Jacobs. As Lord Woolman (2016) notes, "As he signed them many weeks later, he had ample opportunity to cross-check Taylor's classification against the findings of the Q-system" (paragraphs 65, 183 and 185).

The $Q$ value is determined on the basis of three parameters multiplied by one another and adjusted by a fourth according to the importance/use of the tunnel (Barton et al. 1974; Norwegian Geotechnical Institute (NGI) 2015):

The first parameter is $\mathrm{RQD} / J_{n}$ which translates as degree of jointing (or block size).

RQD was originally defined as a simple index for assessing rock quality in boreholes (Pells et al. 2017). It is measured as the percentage of rock core (typically over 1 or $1.5 \mathrm{~m}$ ), recovered in pieces that are $100 \mathrm{~mm}$ or more in length. It is fair to assume that the RQD in this case was approaching $100 \%$ in terms of observable joints lacking any tensile strength, other than in the zone of QMS with flaky slabs.

$J_{n}$ is more difficult to define. Norwegian Geotechnical Institute (NGI) (2015) states that "Joints within a joint set will be nearly parallel to another and will display a characteristic joint spacing". The Geological Mapping Sheet, reproduced in Fig. 7, shows one dominant fault structure, dipping at 48/300. The fault zone has an apparent thickness of about $2.5 \mathrm{~m}$ meaning a true thickness of about $1.7 \mathrm{~m}$. One joint measurement in the side walls is given as 80/110 with the adjacent rock described as "many polished undulating QMS joint surfaces forming thin flakey slabs". No doubt the RQD would have been measured as lower than $100 \%$ if these close, weakly bonded, incipient fractures had been included, as open joints. This is an example of where engineering judgement is required, and it was incipient fractures like these, induced by tectonic stress and probably pervasive for many metres away from the tunnel, that probably resulted in the fine rock mass that blocked the tunnel at the upstream end (Fig. 10).
The fault zone and much of the rest of the rock is described as "moderately weak to moderately strong". It can be interpreted that BS:5930 1999 was being used for the description, rather than BS EN ISO 14689-1:2003 which uses a different range of strengths and lacks the term 'moderately weak'. 'Moderately weak' rock as defined in BS:5930 (British Standards Institution 1999) has uniaxial compressive strength from 5 to $12.5 \mathrm{MPa}$ and pieces can be broken by hand. This is a remarkably low strength for a rock that is otherwise described as 'fresh' and might be explained by incipient disintegration.

For this exercise, Taylor chose to classify the rock as three joint sets plus random, which would designate $J_{n}$ as 12 . All in all, RQD $/ J_{n}$, would probably equal 8.3.

The second parameter is $J_{\mathrm{r}} / J_{\mathrm{a}}=$ Joint Friction.

Norwegian Geotechnical Institute (NGI) (2015) does not provide a parameter for 'polished' joints. The parameter for smooth/undulating joints (as recorded on Taylor's sheet) is 2 , but my intuition would be to assume that the value for slicken-sided, planar joints might be more appropriate (0.5). For $J_{\mathrm{a}}$, I would judge a value of 4 (assuming no infill, but with talc coating (as recorded in the Mapping Sheet) and a residual friction value ' $\emptyset_{r}$ ' of $8^{\circ}-16^{\circ}$ ).

So, my estimate for $J_{\mathrm{r}} / J_{\mathrm{a}}$ would be between 0.5 and 0.125 .

The third parameter is 'Active Stress' and $=J_{\mathrm{w}} / \mathrm{SRF}$, where $J_{\mathrm{w}}$ is a 'Joint water reduction factor' and SRF is a 'Stress Reduction Factor'. $J_{\mathrm{w}}$ is 1.0 (dry excavation or minor inflow). The Stress Reduction Factor would not be too high - there was no evidence of rock bursts other than the interpretation of the post-failure picture, reproduced at Fig. 10, or swelling and a value of 2.5 might be appropriate (single weak zone at depth $>50 \mathrm{~m}$ )

So, $J_{\mathrm{w}} / \mathrm{SRF}=1 / 2.5=0.4$.

That means that the rock quality, $Q$ value would range between $8.3 \times 0.5 \times 0.4(=1.66)$ and $8.3 \times 0.125 \times 0.4$ $(=0.415)$ for Taylor's classification of $3+r$ (joint sets). These numbers relate to 'poor' to 'very poor' rock mass qualities as defined in the $Q$ classification.

1.66-0.415 was probably the value that Jacobs were using to check Taylor's assessment of the need for rock support. Firstly, however, an Excavation Support Ratio (ESR) must be defined. This is tunnel span in metres/ $\mathrm{ESR}$, which can be taken as $5 / 1.3=3.85$. For water tunnels (excluding high pressure penstocks) the recommended value of ESR is 1.6. ESR $=1.3$ is recommended for surge chambers and access tunnels; ESR $=1.0$ is recommended for power houses and civil defence chambers (Norwegian Geotechnical Institute (NGI) 2015).

To use these values, it is necessary to examine the support class graph, reproduced here at Fig. 13. There would be some support required in the crown, less so in the walls of the tunnel and certainly no need for a fully lined option of $100 \%$ shotcrete $(100 \mathrm{~mm})$ and bolts. This 
Fig. $13 Q$ support chart from (Norwegian Geotechnical Institute (NGI) 2015)

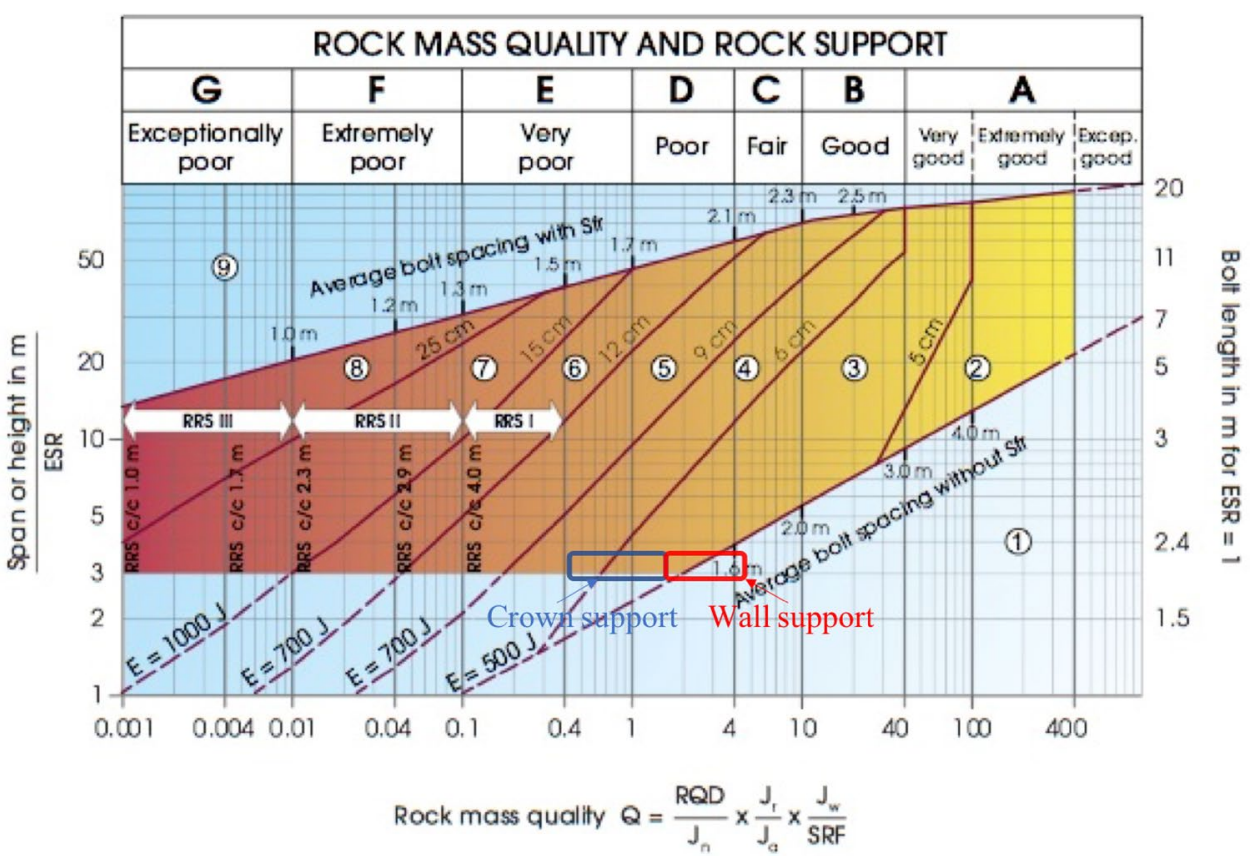

complies with what was done (Class 2 plus backfilling of voids with shotcrete).

Lord Carloway (2018) makes a great deal in his Appeal opinion of the quote from Taylor's assessment note of "Some shear zones with QMS kakerite, local slab formation and blockfall in sidewalls"- assuming that 'kakerite' equates to erodible rock that should have been shotcreted automatically. It is a term which was referred to 23 times by the Chairman of the Appeal in his opinion (Carloway 2018) who supported the Contractor's position and was also referred to by the other two Lords of Appeal (Menzies 2018; Glennie 2018), who overturned the original finding for the Contractor.

But as stated earlier, kakerite (sic) bands-one of the only two fault descriptors specified-can be narrow and nonerodible (in Class II) and, despite the fact that a shear zone was recorded by Taylor, this is not shown on his Geological Fold Out Map presented in Fig. 8. It must be concluded that the shear zones were not considered as important to stability or were too narrow to map. In hindsight, the probable cause of the collapse, in my opinion, was the overall "moderately weak to moderately strong" rock structure, with multiple polished surfaces of low frictional strength, and a third joint dipping in a direction approximately 200 , forming a wedge. The nature of a large-scale collapse due to weak, incipient fractures, was not dealt with well in the risk table (Table 1), should have been indicative of Class III or even Class IV rather than Class II, and was a hazard that was not apparently recognised by any of the parties that inspected the tunnel.

\subsection{Inspections}

Inspections by the designers (Pöyry) and the Owners engineer, Jacobs, apparently checking the rating using the Q-system, failed to identify any areas of concern (Woolman 2016, paragraph 65). Indeed, at the CFZ, the SSE resident engineer had recorded in minutes to a meeting that conditions were Class I throughout and that "the indications of its existence were imperceptible" (Woolman 2016, paragraph 71).

What one can glean from this is that the observing geologists and engineers failed to identify the potential mechanism of collapse despite careful, focussed inspection.

According to Woolman (2016, paragraph 74), prior to the handover, the parties conducted several metre-by-metre inspections of the tunnel, specifically to decide on whether any sections required additional support. Professor Broch, described the rock as "very good" and "more than good enough for a tunnel that is basically designed and built as unlined". The tunnel designers, Pöyry, required "strips of shotcrete and mesh" to be placed to cover "certain areas of erodible rock". This action should have dealt with any exposed zones of erodible kakirite.

There is one additional, publicly available, photograph showing conditions in the HRT. This is reproduced in Fig. 14 and is apparently a British Geological Survey photograph, taken well away from the CFZ. Note that the rock in the tunnel walls is intensely folded and faulted and that the tunnel is not shotcreted. This is, no doubt, an example of Class 1 rock but the chance of predicting failure in this convoluted rock mass is slight. There are no numerical modelling methods of which I am aware that can deal with such ductile, undulating 


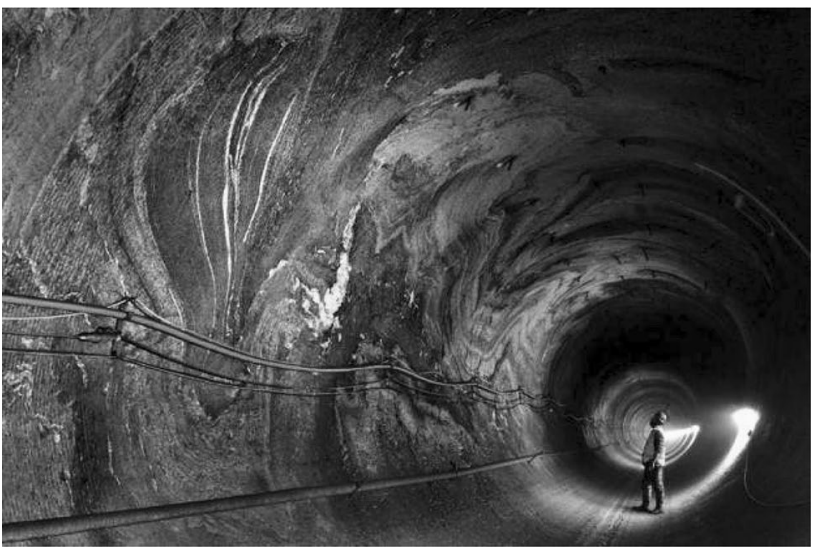

Fig. 14 Folded and faulted (ductile) ground in the Glendoe high race tunnel-well away from the Conagleann Fault Zone (BGS photo)

bands and slithers of rock. If the judgement by the tunnel engineers or geologists, utilising the Q-system, was that no support was required, so be it. There does, however, remain an unquantifiable risk that collapse might occur, which could only be dealt with by lining the tunnel.

It can be concluded, therefore, that the tunnel had been inspected by all parties and found to be stable as far as it is possible to state this for an unlined tunnel. The only option to limit the risk (from unknown, unknowns) would have been, and should have been, a lined tunnel, possibly for the full length of the tunnel, an option that was invited at tender but presumably rejected as safe but too expensive. The risk of collapse, even following joint inspections by qualified experienced people, remained for the SSE-not the Contractor, since the unlined option was chosen (by the Owner) as acceptable at the bid and construction stages.

\subsection{The Borehole}

One strange anomaly is that in the spring of 2008, "Hochtief tried to find out more about the CFZ (Conagleann Fault Zone)" by drilling a borehole (unknown method) at intake 15 (Woolman 2016, paragraph 78). One must ask, why was that expensive operation carried out, considering that the tunnel provided $100 \%$ exposure of the rock at a diameter of $5 \mathrm{~m}$ and had been inspected by numerous professional people, and the support requirements had been approved on behalf of SSE on 20th September in 2007 (Fig. 7). "The attempt was unsuccessful, however, because of adverse ground conditions" and the borehole was abandoned $28 \mathrm{~m}$ above the tunnel crown. This operation, that was surely carried out with the knowledge and approval of SSE, was presumably to find the CFC and yet was abandoned "because of adverse ground conditions", essentially, just above the tunnel. What might an engineering geologist conclude from this? He would conclude that the ground conditions above the tunnel (in a borehole of diameter $100 \mathrm{~mm}$ or so) were considerably worse than those inspected in the tunnel.

\subsection{Investigation}

On 14th August 2009, the first inspection was made following the failure and it is evident that the collapse was continuing at that time from the sounds of rock falling (Woolman 2016, paragraph 106). It is evident that, at the downstream end, the collapse comprised large boulders of irregular shape that had clearly fallen from the roof (Fig. 12). These blocks were not joint bounded but were irregularly shaped, fresh (there is one block that has a red-brown discoloured surface) and probably from a fault zone, which must be upstream of the point where the photo was taken. There are, apparently, no detailed reports available on the nature of the collapsed zone because the collapse "ceased to be a priority issue once SSE elected to construct a bypass tunnel" (Woolman 2016, Paragraph 148). There are, however, a few clues. Figure 10 is a photograph, taken from upstream, showing the tunnel completely blocked by comminuted, fine debris. The tunnel walls show evidence of folding and faulting. As Smith (a geologist from the British Geological Survey, BGS, but not, as Lord Woolman (2016) emphasised in paragraph 151, an engineering geologist) put it, "If you wanted to build a tunnel in the area, you couldn't have picked a worse spot in terms of structural complexity".

The area is certainly structurally very complex and one might expect an adequately trained and experienced engineering geologist to get it right, more often than not, if the site was "forgiving" rather than "unforgiving"-i.e. with inherent and hidden engineering geological problems that might be beyond the ability of any professional engineering geologists, to identify (Hencher 2012, page 116). Indeed, with a range of experienced inspectors, examining the walls of the tunnel, no bells were rung. Each stage of rock excavation classification and geological mapping was provided to Pöyry and to Jacobs asking: "Please advise if the classification or support specification is at variance with your observations or design assumptions"; but there was no evidence that anyone queried Taylor's decisions (Woolman 2016, paragraph 63). Mr. David Fawcett (ex BTS Chairman) wrote: "There is no recorded evidence of passing through any feature that could potentially cause the catastrophic collapse that has occurred"- -but the tunnel failed (Woolman 2016, paragraph 181).

Mr. Taylor recorded the presence of mica schist kakerite on his sheets but as Lord Woolman (2016, paragraph 176) stated: "Why go to the trouble of identifying such features and then to decide not to do anything about it?" The point is that if the kakirite was considered thin and non-erodible, one would do exactly as was stated, erect Class II support to 
the crown. The collapse was, as Dr. Büchi, one of the experts put it, a "geological accident" (Woolman 2016, paragraph 151) but would not one have anticipated such an accident, somewhere along the $6.2 \mathrm{~km}$ of tunnel in structurally complex rocks, subjected to high water pressures? How long would it last -1 year, 2 years, 10 years or 75 years? On 23rd June, 2008, SSE informed Hochtief that the scheme had achieved its availability guarantee of $99 \%$ but on 4th August a "plume" of sediment was noted issuing and within a year the tunnel had collapsed.

If you want and require a low risk tunnel for 75 years, you line it and pay for the lining. If you are prepared to accept a risk, then you do not. Interestingly, SSE were, apparently, prepared to pay for any lining that was advised, during the works (Woolman 2016, paragraphs 166 days and e; Glennie 2018, paragraph 387).

There was no financial advantage to Hochtief to leave 96\% unlined (with localised shotcrete), or to leave any erodible rock exposed; it was a joint decision of what was erodible and what class of support was required, based on the expertise of the geologists. If the geologists got it wrong, so be it.

\subsection{The Experts Views on Lining the Tunnel}

At Glendoe, Lord Woolman (2016) summarised at paragraph 153 that all of the tunnelling experts "agreed that it was appropriate (a) to excavate the tunnel by means of a TBM (b) to adopt an unlined design concept, and (c) to use the observational method of rock classification". This is a tacit acceptance of risk of rock fall by SSE and all the experts involved, none of whom argued otherwise.

As previously stated, that opinion is moderated by the decision, presumably by SSE, that the 550-m by-pass tunnel, post-failure, should be fully lined with 500-mm-thick, secondary concrete (Appleyard 2012). That is substantial lining, far more than would have been put in if the rock had been perceived as Class 4 originally. For the rest of the tunnel, a lining of $100 \mathrm{~mm}$ has been applied to almost $50 \%$ of the length (Appleyard, op cit). It is to be noted that there remains a risk of rock fall in the other $50 \%$ of the tunnel, that risk to be accepted, presumably, by SSE.

Geotechnical risk is often larger and may be more catastrophic than perceived. As Baecher and Christian (2003) summarise it: "People—even experts—rarely assess their uncertainty to be as large as it usually turns out to be". The way in which geologists reach decisions, based on their previous experience, is addressed by Polson and Curtis (2010), showing how original opinions are tempered and brought to some consensus (right or wrong). An example is discussed by Hencher (1996), concerning Nirex assessments of permeability of the Brockram Rock at Sellafield.
This case demonstrates how a group of experts, faced with a particular set of data, came up with an incorrect probability distribution function ('pdf'), because the data set was too small to include high permeability data from widely spaced master joints as revealed by a later borehole. All of the original numerical modelling had to be rerun.

\subsection{The Opinion of Lord Woolman}

The basic philosophy of constructing the tunnel needs to be borne in mind. The tunnel was to be essentially unlined and was to be pressurised periodically over 75 years. During that 75 years, it was anticipated that blocks of rock would fall from the roof. Broch (2000) summarised it:

"As long as rockfalls in certain parts of the tunnel don't occur frequently and increase the head loss, a reasonable number of small blockages spread out along the tunnel will not harm the tunnel or disturb the operation of the hydro power station."

That is a wish, not an engineering solution, but it is what SSE bought, in ordering a partially lined tunnel, and agreed with, following detailed metre-by-metre inspections by geologists and engineers.

The SSE assumed risks, except for a defect that existed at takeover, which was defined as: "part of the works that is not in accordance with the Contractor's design which has been accepted by the Project Manager" (Woolman 2016, paragraph, 160). Any defect that was recognised should have been notified by the Contractor to the Owner prior to handing over the tunnel.

In this case, the tunnel apparently conformed to the Contractor's design as found by the Adjudicator, as referred at Sect. 3.7, (a situation that is disputed by Lords Menzies and Lord Rennie as discussed below) and, in my view was accepted by the PM as per the signed off sections of the tunnel classification by Jacobs in the RECs, on behalf of SSE, and the statement on 23rd June, 2008 whereby SSE informed Hochtief that the scheme had achieved its availability guarantee of 99\% during the first 6 months period (Woolman 2016, paragraph 88).

The geological conditions that led to the failure were not evident to anyone who examined the tunnel and checked the design, which was in accordance with the Contractor's design and, in accordance with Option $\mathrm{M}$, which states that:

"The Contractor is not liable for Defects in the works due to his design so far as he proves that he used reasonable skill and care to ensure that it complied with the Works information." (Woolman 2016, paragraph 162). 
The non-evident nature of the 'defect' is apparent; otherwise, the tunnel would not have been 'accepted'.

The Contractor evidently exercised reasonable skill and care as was explained by Lord Woolman:

"Many experienced tunnellers scrutinised the HRT both during and after the TBM drive. They included engineering geologists, tunnel designers, engineers and the TBM crew; they were actively looking for problems. None of them saw any signs of faults that might threaten tunnel stability. None recommended the installation of a higher level of support at particular locations." (Lord Woolman, 2016, paragraph 180).

Lord Woolman concluded (at paragraph 187):

"I am satisfied that Hochtief did exercise reasonable skill and care."

In my opinion, the structure that failed was much larger and beyond the ability of observation by any of the experts who subsequently examined the tunnel mapping. Perhaps, in hindsight, the tunnel should have been lined, arbitrarily, through the fault zone especially and, depending on the risk that SSE was going to accept, perhaps for the whole tunnel.

Lord Woolman (2016) concludes (at paragraph 194) that: "I therefore hold that there was no contributory negligence on the part of SSE in failing to appreciate the significance of the odd readings." That decision is questionable, given the publication on previous tunnel collapses in unlined tunnels by Sandilands, presumably the PM for Glendoe (Cameron and Sandilands 1996). The fact that Sandilands had experience of numerous rock falls from tunnels in Scotland, should, it might be argued, have made him more aware of the risk of failure (that he apparently disregarded for several months).

In his conclusions, Lord Woolman states (at paragraph 260 , e.) that "The collapse was not due to a defect that existed at takeover. Accordingly, it was an employer's risk event". The geological conditions that caused the failure clearly did exist at handover but the hazard (one that would deteriorate with time) remained an 'employer's risk event' in that it was one that was not identified as a 'defect' in design or in implementation of the design, using reasonable skill and care by all parties.

\subsection{The Appeal}

The Appeal was heard in 2018 by three judges: The Lord President (Lord Carloway), Lord Menzies and Lord Glennie. Lord Carloway found for the Contractor, Hochtief (in agreement with the Lord Woolman). Lord Menzies and Lord Glennie found for the 'Pursuer'-SSE.
Lord Menzies examines two 'limbs' to the case (Menzies 2018, paragraph 339). The first is regarding time. He argues that a tunnel that was supposed to last for 75 years, that collapsed before the 'Defects date', after 4 years, could not be fit for purpose. This argument does not persuade me, as the 75 years, which everyone who examined the tunnel agreed that the tunnel should have lasted, was an Objective not a Requirement (Lord Menzies 2018, paragraph 342). Why the Defects date is relevant is not explained; what would have been the situation if the collapse had occurred after the 'Defect Period'?

The second point concerns Table 11 (Table 3 is a simplified version) (paragraph 345). It is argued that because kakirite (kakerite) was recorded in Taylor's sheet that it should have led to shotcrete cover. Lord Menzies (2018) makes the statement at paragraph 346: "As your Lordship in the chair observes (at para [259]), it may be assumed from the commercial judge's findings that some erodible rock had not been shotcreted". This is incorrect. 'Kakerite' is not the same as 'erodible kakirite'. There could well be seams of fault breccia that were regarded as non-erodible identified on Taylor's sheet (Fig. 8) but not large enough to be depicted in the map of the tunnel over the same chainages. He wrote: "Some shear zones with QMS kakerite, local slab formation and blockfall in side walls. Rotate CII support to LHS from 2117 to 2107 . Extend shotcrete to maximum extent in shotcrete bay and backfill voids" on the relevant REC, reproduced here as Fig. 7. As far as I am concerned, this was (a) recognising the localised problem and (b) dealing with it.

In paragraph 349, Lord Menzies (2018) expresses his opinion that the design was never accepted by the Project Manager for the purpose of clause 21.2, "Although $\mathrm{Mr}$ Sandilands may have indicated his informal approval, this could not amount to formal acceptance for this purpose." This raises the question of at what stage was the design accepted and by whom? It is clear that the REC for chainages 2101-2117, reproduced in Appendix 5 of Lord Carloway's opinion (Carloway 2018), was signed as "Approved (for SSE)" (see Fig. 7). On 18th December 2008, the tunnels and power station were taken over by the Employer as "sufficiently complete for safe operation" (Woolman 2016, paragraph 79). In my view this means that the design, with its risk, was accepted by the Owner.

Lord Menzies (2018) considers the failure, accepting Lord Woolman's view of the importance of 'erodible rock'. He points out the importance of 'erodible rock' in Table 3 which constituted part of the design. The remedy for 'erodible rock' was 'application of shotcrete if not already covered/"protected" by steel rib support". Class IV support was the only remedy involving steel sets and was not in fact used anywhere in the tunnels.

This view of the cause of the failure conflicts with Lord Woolman's astute observation of "why go to the trouble 
of identifying such features and then decide to do nothing about them?" (Woolman 2016, paragraph 176). This was not 'painting by numbers'-it was judgement of engineering geological risk, checked and approved by other professional and highly experienced engineering geologists such as Derek Williams (of Jacobs).

In my opinion, an alternative explanation to the 'erosion theory' is that the rock collapsed as a series of wedges with structural geological control. Downstream, the wedges were generally large, involving blocks of rock of $1 \mathrm{~m}$ or greater (see Fig. 11). The upstream part of the failure may have involved collapse of fragments of rock released by incipient discontinuities, resulting in the comminuted pile of fine debris as seen in Fig. 9.

Lord Menzies considers the design life of 75 years, but as noted earlier, the experts and engineering geologists had this in mind when handing over the tunnel. That was their judgement, but which proved incorrect. If SSE wanted a tunnel with no risk of collapse, then they should have instructed a fully lined tunnel, especially considering their earlier experience with unlined tunnels (Cameron and Sandilands 1996).

Lord Glennie (Glennie 2018, paragraph 364-367) considers the term defect and finds that there was no defect in design. "The Defect" (causing the collapse) "was not one of design but rather implementation of that design" (paragraph 375). He argues that the REC (Tables 1,2) was not complied with, with all sections of "erosion of erodible rock during operation" covered with shotcrete and that it follows that the implementation of design was incorrect.

He misses the point completely that kakerite (sic) was noted on the REC but not 'erodible kakerite'. No such material was logged on the Geological Fold Out Mapping Sheet in Fig. 8. Lord Glennie assumes that the REC exhibited in Table 1 is complete and fool-proof as a design tool. That is incorrect. What, one might ask, should the engineering geologist have done about the weak rock exposed in the side walls, with polished surfaces? It says nothing about such rock in the REC, which it must be argued, was there as a design aide, to assist the engineering geologist in his decisions at the tunnel face. The design decision was taken by the engineering geologist, and then checked by various parties, to ensure that the tunnel was adequate and would (should) remain so for 75 years. During that design life, the normal actions of water hammer and surges would be anticipated, which can create positive and negative water pressures periodically in the tunnel walls. The fact that it did not last the full 75 years is a consequence of how much risk the Owner was prepared to take and the unforeseen ground conditions, despite $100 \%$ exposure in the tunnel walls.

In other words, I believe that the opinions of Lords Glennie and Menzies (2018) are questionable, based on legalistic interpretations of Table 1, that any hard-rock tunneller would find surprising. It exposes the difficulties in approaching geotechnical and geological matters as if they were points of law and highlights the advantages of an arbitration system, run by one or three professionals, appointed as agreed by the parties.

\section{Discussion}

Geotechnical risk is always difficult to address as ground and environmental factors can be very complex, leading to geological conditions that are rare or even completely new to the engineer. For example, a slope in Brisbane, that was originally designed on the basis of a few boreholes and trial pits as is standard, took more than 4 years of subsequent effort by teams of professionals including geologists and geophysicists and more than $5 \mathrm{~km}$ of additional drilling and other ground investigation, before the decision was taken to remove the top of the hill that was driving the failure (Wentzinger et al. 2013). Another example is the Ping Lin Tunnel, in Taiwan in which two $11.84 \mathrm{~m}$ TBMs had to be abandoned and the tunnelling method changed to drill and blast due to unexpectedly high water inflow. The tunnel took several additional years to complete and considerable loss of life (Barla and Pelizza 2000).

At Glendoe, all the tunnelling experts agreed that an 'unlined' tunnel solution was acceptable (Woolman 2016, paragraph 153), leaving a major risk of tunnel collapse, as occurred. The lifetime of the tunnel of 75 years, made much of by the Appeal judges, was an Owners Objective not a commitment by the tunnel designers. To quote Lord Woolman (2016, paragraph 163 and 164):

"Hochtief did not guarantee the works. Instead it accepted the familiar and lesser obligation of 'reasonable skill and care'. and,

"If SSE's interpretation was correct, it would mean that Hochtief had an overarching obligation to provide tunnels suitable for their purpose. ... It would effectively rob Option M of its meaning."

The level of support that was decided on by David Taylor of Hochtief was approved by Derek Williams of Jacobs on behalf of SSE. In my view, the engineering geologist, Taylor and all the others that examined the tunnel, were not negligent. They simply did not recognise the nature and scale of the problem that arose in the CFZ, that was much larger than the 'aide memoire' Mapping Sheets, with the void extending more than $100 \mathrm{~m}$ away from the tunnel. The fact that the tunnel collapsed over such a large length is evidence that the support system was not, in the event, adequate, even though it had been judged as sufficient, 
within the tunnel, at the time of handover, by all parties. In hindsight, the only way of preventing collapse would have been to use water-proof lining, probably $500 \mathrm{~mm}$ thick for the full fault zone, as was adopted in the by-pass tunnel following the collapse. Even that measure, combined with lining more than $3 \mathrm{~km}$ of the tunnel with shotcrete, which has been conducted retrospectively, is no guarantee that the tunnel will remain open for 75 years. There remains a geotechnical risk that, it is presumed, still must be borne by the Owner, SSE.

\section{Conclusions}

The case of responsibility for the Glendoe tunnel collapse was first adjudicated then subjected to a court case over an "action of damages" that was later appealed (Carloway 2018, paragraph 1). As a result, the case has been overturned in favour of the "Pursuer" on the basis of technical and contractual grounds that are not proved in my opinion. The case is now scheduled to be heard in the Supreme Court.

Regarding the technical causes of the collapse, this paper highlights some of the geotechnical findings that were not accounted for in the judgement.

In particular 'kakerite' or kakirite was wrongly assumed by all the judges to be inherently erodible. In my opinion, given the choice of descriptors between 'kakerite' and mylonite for fault rocks, in Class II of the REC sheet, the term 'non-erodible' was used to define non-erodible kakirite- such as cemented fault gouge.

That being so, in the absence of erodible rock, there is no need to assume that Class III or Class IV should have been automatically applied.

The opinion of Lord Woolman (2016) regarding cause that "(2) The weak rock deteriorated and lost its strength when submerged, a process Professor Stille referred to as 'slaking'. (3) The flowing water washed out areas of erodible rock", whilst possible, is not supported by evidence. Professor Broch searched the tunnel for swelling minerals and the tests conducted showed none.

In my opinion, an alternative and more likely explanation is that the failure was largely due to a complex and very large wedge failure. There are two adverse joint measurements in Fig. 8 and the rating of the rock mass was ' $3+r$ ' (meaning three sets plus random joints). In my view such large-scale wedge failure is far more likely an explanation for the faulted structure which ravelled away from the tunnel by up to $172 \mathrm{~m}$. It is likely that this was compounded by the presence of 'fresh moderately weak' rock in the tunnel. That this rock was described as 'fresh' means that it must have been disintegrated presumably by tectonic action, rather than decomposed.
Contractually, there is the question of whether or not, and when the tunnel was 'accepted' by SSE. There seem to be four factors:

1. The tunnel was to be 'design and build'. SSE accepted that the tunnel would have a thin lining for less than $1 \%$ of its length, whereas, their consulting engineer, Jacobs, had predicted $100 \%$ lining for a drill and blast tunnel. I remain unconvinced that forming a tunnel by TBM would really reduce the risk to that extent but I agree with Professor Grøv that geological details might be difficult to make out in a TBM tunnel with 'rifle bore' finish.

2. As the tunnel was constructed, RECs were submitted to the supervising engineer, to check (using the Q-system). There was no disagreement over the classes of support that were defined. The RECs were formally 'approved' by the checking engineer on behalf of SSE.

3. There was to be a defects period of 2 years after completion. It is stated, however, that the Contractor was, apparently as a generality (Carloway 2018, paragraph 11):

"not liable for defects in the works due to his design so far as he proves that he used reasonable skill and care to ensure that it complied with the works information."

It seems evident that, by the inspections by all parties of the tunnel walls on a metre-by-metre basis, that reasonable skill and care was taken.

4. On 23rd June 2009 Hochtief were informed that the scheme had achieved its availability guarantee of $99 \%$ during the first 6 months period. (Woolman paragraph 88).

It is my opinion that the tunnel was accepted by SSE from Hochtief and that the risks from tunnel collapse, in the essentially unlined tunnel, were then taken on by SSE.

Acknowledgements This paper has benefited considerably and become much clearer following dutiful and expert reviewing (several times) by Dr. Trevor Carter, Principal Geological Engineer, from Golder Associates, Toronto, Canada and by Professor Giovanni Barla, Editor of the Journal.

Open Access This article is distributed under the terms of the Creative Commons Attribution 4.0 International License (http://creativeco mmons.org/licenses/by/4.0/), which permits unrestricted use, distribution, and reproduction in any medium, provided you give appropriate credit to the original author(s) and the source, provide a link to the Creative Commons license, and indicate if changes were made. 


\section{References}

Anon (1995) The description and classification of weathered rocks for engineering purposes. Geological Society Engineering Group Working Party Report. Q J Eng Geol 28:207-242

Appleyard D (2012) Reopening Glendoe after a rockfall. p 3. http:// hydroworld.com. Accessed 5 Jan 2012

Baecher GB, Christian JT (2003) Reliability and statistics in geotechnical engineering. Wiley, New York, p 605

Barla G, Pelizza S (2000) TBM tunnelling in difficult conditions. In: Proceedings of GeoEng 2000, Melbourne, Australia, pp 329-354

Barton N, Lien R, Lunde J (1974) Engineering classification of rock mass for the design of tunnel support. Rock Mech Rock Eng 6(4):189-236

British Standards Institution (1999) BS 5930:1999 Code of practice for site investigation. p 206

Broch E (2000) Unlined high pressure tunnels and air cushion surge chambers. AITES-ITA 2000 World Tunnel Congress. South African Institute of Mining and Metallurgy, Durban, pp 63-72

Cameron AT, Sandilands NM (1996) North Lochay tunnel repairs. In: Proceedings institution of civil engineers water, maritime and energy, p 118, March 21-28

Cameron AT, Sandilands NM (1997) Discussion, 124, June, 127-129

Carloway L (2018) First division, Inner House, Court of Session, opinion of Lord Carloway, the Lord President in the reclaiming motion of SSE Generation Ltd against Hochtief Solutions AG and Another, pp 1-139, [2018] CSIH 26 CA162/12

Fookes PG (1997) Geology for engineers: the geological model, prediction and performance. Q J Eng Geol 30:293-431

Glennie L (2018) First division, Inner House, Court of Session, opinion of Lord Glennie in the reclaiming motion of SSE Generation Ltd against Hochtief solutions AG and Another, pp 151-176. [2018] CSIH 26 CA162/12

Hencher SR (1996) Fracture flow modelling: supplementary proof of evidence. In: Haszeldine RS, Smythe DK (eds) Radioactive waste disposal at Sellafield, UK: site selection, geological and engineering problems. University of Glasgow, Glasgow, pp 359-370

Hencher SR (2012) Practical engineering geology. Spon Press, London, p 450

McClay KR (1987) The mapping of geological structures. In: Geological society of London handbook, p 161

Menzies L (2018) First division, Inner House, Court of Session, opinion of Lord Menzies in the reclaiming motion of SSE Generation Ltd against Hochtief Solutions AG and another, pp 140-150, [2018] CSIH 26 CA162/12
Morgenstern NR, Cruden DM (1977) Description and classification of geotechnical complexities. In: Proceedings of the international symposium on the geotechnics of structurally complex formations, Associazone Geotecnica Italiana, Rome, 2, pp 195-204

Norwegian Geotechnical Institute (NGI) (2015) Using the Q-system. Stryn, Norwegian Geotechnical Institute, p 54

Palmström A, Berdal AB (1987) Norwegian design and construction experienced of unlined pressure shafts and tunnels. In: International conference on hydropower, Oslo, Norway, p 10

Pells P, Bieniawski ZT, Hencher SR, Pells S (2017) RQD: time to rest in peace. Can Geotech J 54(6):825-834

Polson D, Curtis A (2010) Dynamics of uncertainty in geological interpretation. J Geol Soc Lond 167:5-10

Reynolds P (2017) Judgement for contractor over Glendoe collapse. TunnelTalk, 12 Jan 2017, 3p

Sibson RH (1977) Fault rocks and fault mechanisms. J Geol Soc Lond 133:191-213

Terzaghi K (1946) Rock defects and loads on tunnel supports. In: Proctor RV, White T (eds) Rock tunnelling with steel supports. Youngstown, Commercial Shearing and Stamping Co., pp 15-99

Wentzinger B, Starr D, Fidler S, Nguyen Q, Hencher SR (2013) Stability analyses for a large landslide with complex geology and failure mechanism using numerical modelling. In: Proceedings international symposium on slope stability in open pit mining and civil engineering, Brisbane, Australia, pp 733-746

West G (1983) Comparisons between real and predicted geology in tunnels: examples from recent cases. Q J Eng Geol Hydrogeol 16:113-126

Whitten DGA, Brooks JRV (1972) The Penguin dictionary of geology, Penguin Books Ltd., Harmondsworth, Middx, p 495

Winter J (2000) Clause 12: keep it out of the court. Construction News, 15 th June, $\mathrm{p} 2$

Woodcock NH, Mort K (2008) Classification of fault breccias and related fault rocks. Geol Mag 145(3):435-440

Woolman L (2016) Outer House, Court of Session, opinion of Lord Woolman in the cause SSE Generation Limited against Hochtief Solutions AG and another, [2016] CSOH 177 CA162/12

Publisher's Note Springer Nature remains neutral with regard to jurisdictional claims in published maps and institutional affiliations. 